\title{
An overview of the limnetic Cyclopidae (Crustacea, Copepoda) of the Philippines, with emphasis on Mesocyclops
}

\author{
Rey Donne S. PAPA,${ }^{*}$ Maria K. HOŁYŃSKA ${ }^{2}$
}

${ }^{1}$ Department of Biological Sciences and Research Center for the Natural and Applied Sciences, University of Santo Tomas, España Boulevard, 1008 Manila, Philippines; ${ }^{2}$ Museum and Institute of Zoology, Polish Academy of Sciences, Wilcza 64, 00-950 Warsaw, Poland

*Corresponding author: rspapa@mnl.ust.edu.ph; reypaps@yahoo.com

\begin{abstract}
Approximately 120 (sub)species of Cyclopidae have been reported from South and Southeast (SE) Asia, where the Philippine archipelago - with 16 (including two endemic) taxa - is one of the least explored parts of the region. Our study, part of current efforts to assess freshwater biodiversity, was undertaken to update the diversity and geographic distribution of the cyclopid copepods living in the limnetic zone of the freshwater lakes in the Philippines. Examination of the samples from 22 lakes in five islands (Luzon, Mindoro, Cebu, Leyte and Mindanao) revealed a novel species from lake Siloton (Mindanao), Mesocyclops augusti $n$. sp. The new species can be distinguished from the congeners by the surface ornamentation of the hindgut, among others. The same character state was found in a Mesocyclops from North Vietnam, which is provisionally identified as M. augusti $n$. sp., though the Vietnam and Mindanao specimens differ in a few (yet polymorphic in the close relatives) characters. Mesocyclops microlasius Kiefer, 1981 endemic to the Philippines is redescribed, based on females and males from lake Paoay (North Luzon). Sister relationships of M. augusti $n$. sp. and M. microlasius were tested in a phylogenetic analysis that included the closely related Old World representatives of the genus. The max. parsimony trees show M. dissimilis Defaye et Kawabata, 1993 (East Asia) as the closest relative of M. augusti n. sp. (Mindanao, Vietnam), and support sister relationship between M. geminus Holynska, 2000 (East Borneo) and M. microlasius (Luzon, Mindanao). A mainland clade (M. francisci, M. parentium, M. woutersi, M. dissimilis, M. augusti) appears in most reconstructions; all members of the clade occur in continental Asia though some species also live in islands that have never been connected to the SE Asian shelf. In most trees with the mainland clade the insular taxa (M. microlasius, M. geminus, M. friendorum) form either a paraphyletic (basal to mainland) or monophyletic sister group of the mainland clade. We also established the first records of Thermocyclops taihokuensis (Harada, 1931) in the Philippines (Luzon), so far known from East and Central Asia. In all, 11 taxa [Mesocyclops (4), Thermocyclops (4), Microcyclops (1), Tropocyclops (1) and Paracyclops (1)] including only one endemic species (M. microlasius) have so far been found in the limnetic waters. We expect significantly higher diversity and higher rate of endemism of the freshwater cyclopids in the littoral (paludal) and subterranean habitats in the Philippines.
\end{abstract}

Key words: Biodiversity, tropical lakes, Luzon, Mindanao, zoogeography.

Received: Janaury 2013. Accepted: June 2013.

\section{INTRODUCTION}

Cyclopidae [ 1010 (sub)species], as one of the largest crustacean families, is represented by $\sim 120$ (sub)species in South and Southeast (SE) Asia (Boxshall and Defaye, 2008; MH's personal database), and only 39 species have so far been reported from the insular Indo-West Pacific region (Hołyńska and Stoch, 2011). As a dominant component of the lake zooplankton community, cyclopid copepods are considered important prey of larval and adult zooplanktivorous fish (Papa et al., 2008). Their abundances (together with cladocerans) when compared to calanoid copepods are often related to lake nutrient levels and water temperatures, as they have been revealed by long-term investigations of the zooplankton community responses to eutrophication and climate change (Anneville et al., 2007; Chih-hao et al., 2011). Furthermore,
Mesocyclops (and at least one Thermocyclops) species have potential use as biological control agents of Denguecarrying mosquitoes (Aedes spp.). Experiments on the use of copepods in mosquito control have been conducted in several countries including the Philippines, Vietnam, and Australia (Nam et al., 1999; Dussart and Defaye, 2001; Ueda and Reid, 2003; Panogadia-Reyes et al., 2004).

The Philippine archipelago (comprising 7107 islands) are located on the fringe of SE Asia, yet remained separated (though by a narrow strait between the present Borneo and Palawan islands) from the Asian mainland even during the largest sea-level drop during last glaciation (Voris, 2000; Sathiamurthy and Voris, 2006). Diverse connections of the Philippines caused them to be allocated to various biogeographic regions. The Philippines are part of the Oriental region in the Sclater-Wallace system, while the archipelago (except for Palawan) is taken out from the 
Oriental region in the Huxley-scheme. Botanists consider the Philippines as part of Malesia (also including the Malay peninsula, Indonesian archipelago and New Guinea), while in the latest monograph of the zoogeography of the continental waters, the southern and southwestern Philippines (Palawan, Calamianes, Mindoro, Sulu and Mindanao islands) belong to the South Asian subregion (that largely fits the Oriental region) of the Sino-Indian region, and the northern Philippines are part of the IndoWest Pacific peripheral areas also including Wallacea, the Pacific islands and few islands in the cold zone of southern hemisphere (Bănărescu, 1992, 1995). The insular character has favoured a high species richness and endemism in flora and fauna, thus making the Philippines one of the most interesting regions worldwide (Jones and Kennedy, 2008). It is, unfortunately, also recognised as a biodiversity hotspot, due to the high rate of habitat destruction and loss (Ong et al., 2002; Sinha and Heaney, 2006). Inland waters are among the least studied and most threatened habitats for Philippine biodiversity. In other parts of the world they have been found to host a variety of interesting plants and animal taxa (Balian et al., 2008), but have so far escaped the attention of the Philippine biologists. In the Philippines, studies on limnology and freshwater biodiversity have been fragmentary and inadequate, which often led to the formulation of poorly-prepared conservation and management plans, including those for approximately 70 lakes throughout the archipelago (Papa and Mamaril Sr., 2011).

The current body of knowledge on freshwater zooplankton diversity in the Philippines has mostly been made up of contributions of western scientists. In 1872, Carl Semper described a spherical rotifer, Trochosphaera aequatorialis, from rice fields in Mindanao island (southern Philippines) (de Elera, 1895; Mamaril Sr. and Fernando, 1978). This survey was followed by the descriptions of new species and the listing of new records in many lakes and other freshwater ecosystems during the Wallacea-expedition, including the cyclopid copepods Mesocyclops microlasius Kiefer, 1981 and Thermocyclops wolterecki Kiefer, 1938 (Brehm, 1938, 1942; Kiefer, 1938a, 1938b, 1981; Hauer, 1941; Woltereck et al., 1941). Two of the most comprehensive and important papers on Philippine freshwater zooplankton were published by a Filipino - Mamaril Sr. - who listed a total of nine copepod species (Mamaril Sr. and Fernando, 1978; Mamaril Sr., 1986). Only a few researchers have added new species or locality records since then (Petersen and Carlos, 1984; Tuyor and Baay, 2001; Aquino et al., 2008; Papa and Zafaralla, 2011). At present, 16 freshwater cyclopid species have been recorded in the Philippines (Tab. 1), yet some of those species certainly do not occur in the archipelago, or their taxonomic identity needs further verification. On the other hand, hardly anything is known about the cope- pods of the small water bodies, swamps and subterranean waters of the Philippines, which may be home to a much richer fauna including several endemic and/or relict taxa (Brancelj et al., 2013; Van Damme et al., 2013). A focus on the lake plankton forms can only be justified as the first step of a long-term research project on the freshwater copepod fauna of the Philippines.

Here we present an overview of the species diversity and geographic distribution of the cyclopid copepods collected from the limnetic zone of 22 lakes distributed in five major islands (Luzon, Mindoro, Cebu, Leyte and Mindanao) of the Philippines. Among these are lakes where efforts to conserve biodiversity have to be balanced with the need to provide sustainable fisheries-based livelihoods, and where the recent increase in under-regulated aquaculture practices have led to a decline in water quality and increased eutrophication (Tamayo-Zafaralla et al., 2002; Palerud et al., 2008).

A large part of the paper deals with the systematics of a single group, the genus Mesocyclops, and the reasons for this are twofold: i) Mesocyclops is one of the most common and most species-rich components of the tropical lake plankton; ii) the taxonomy of the genus is relatively well understood to pose questions on the phylogenetic relationships/origin of the Philippine species. We describe a new Mesocylops species from Mindanao, provide an amended diagnosis of the endemic M. microlasius, and discuss phylogenetic relationships of these Mesocyclops taxa.

\section{METHODS}

In total, 43 samples collected from 22 lakes were analysed: 15 lakes in Luzon, 4 in Mindanao and 1 each in Cebu, Leyte, and Mindoro islands (Fig. 1; Supplementary Material A). Samples were collected between 2006 and 2011. Plankton sampling was done by towing 50,80 and $100 \mu \mathrm{m}$ mesh-size plankton nets from several transects perpendicular to the lake shore. Littoral and limnetic samples were stored separately unless there was no clear demarcation between littoral and limnetic areas of the lake. The samples were fixed in $10 \%$ formalin and later transferred to $5 \%$ formalin with Rose Bengal dye. Selected specimens from the limnetic samples were dissected and mounted in a glycerin medium. Slides were sealed with nail polish. Dissections were made under an Olympus SZ11 stereomicroscope (Olympus, Tokyo, Japan). Specimens were examined in bright-field and differential interference contrast optics and drawn using a camera lucida attached to an Olympus BX50 compound microscope (Olympus). Telescoping body segments were measured separately. Setae of the caudal rami are denoted by Roman numerals, following the scheme applied by Huys and Boxshall (1991).

With few exceptions, only the females could be identified as available identification keys rarely include characters of the male. Identifications were based on Karaytug 


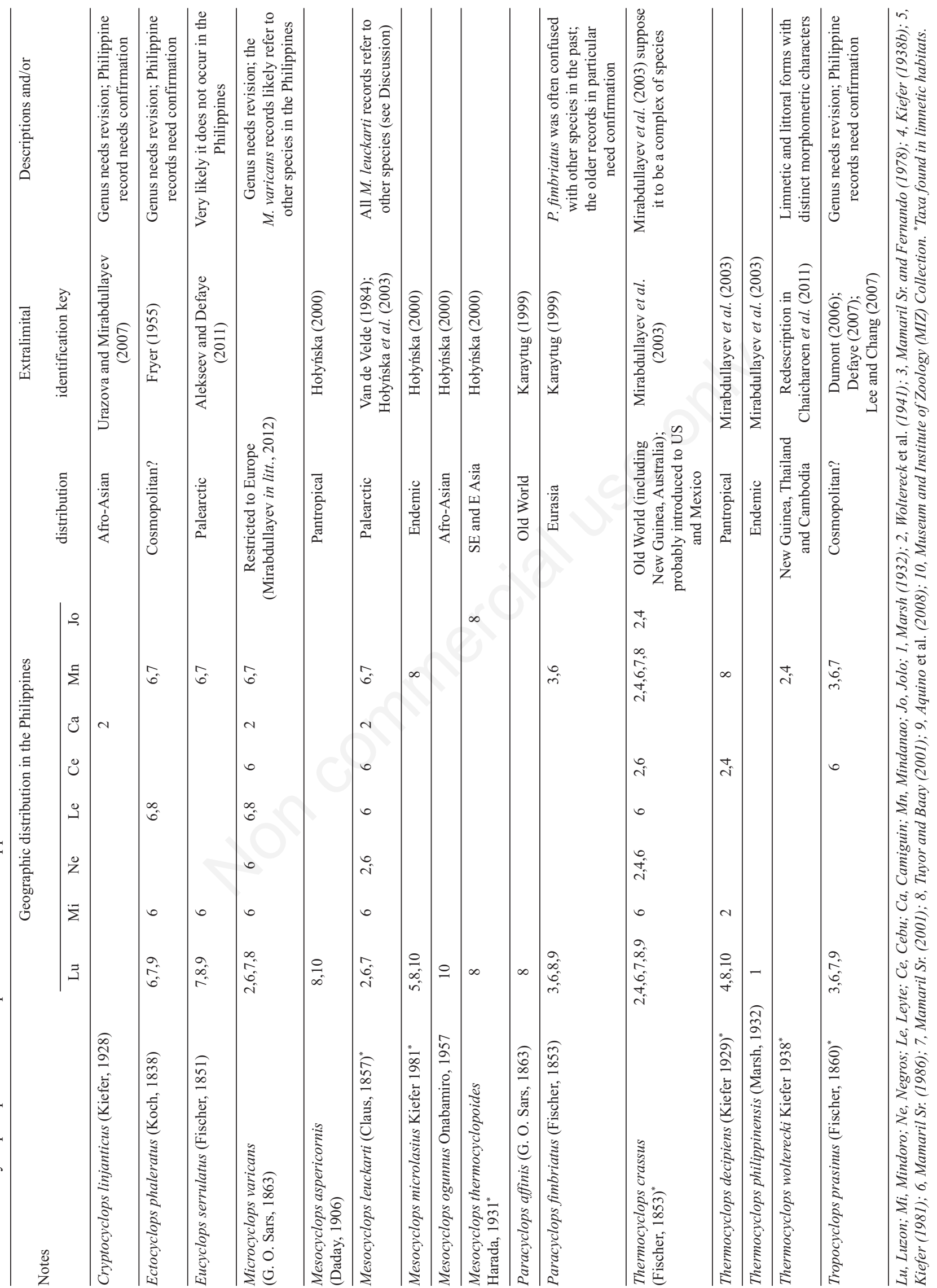


(1999), Ueda and Reid (2003) and Hołyńska (1997, 2000, 2006a)

In search of the sister species of $M$. augusti $\mathrm{n}$. sp. and M. microlasius, we applied the criterion of the global parsimony using Hennig86 version 1.5. The analyses used 18 morphological characters (46 character states) and included the morphologically close Old World representatives of the genus only (Supplementary Materials B and C). In choice of the ingroup and outgroup taxa we relied upon a former phylogenetic analysis (Hołyńska, 2006b) that included all species of the genus. Phylogenetically informative characters that are fixed in some ingroup species can be intraspecifically variable in other members of the ingroup. Portion of the polymorphic traits can be significant in young groups where most speciations happened relatively recently, and time was too short to reach the fixed condition of a novel character state in each char- acter. Exclusion of the polymorphic characters from the phylogenetic analysis (means loss of information) would not only result in worse resolution but also false topology of the trees (Wiens, 2000). Eight characters showed intraspecific variation in some species. Data on character polymorphism were taken from earlier publications (Hołyńska et al., 2003; Hołyńska, 2006b), and on observations of the specimens listed herein.

We treated the polymorphic characters in three different ways (unordered, unscaled and scaled coding). All three coding methods recognise a polymorphic condition as a separate state, the differences between these coding methods being in the presumed numbers of transformations between the states fixed absent, polymorphic and fixed present [for more details see Wiens (2000) and Hołyńska and Stoch (2011)]. In the unordered run, all characters (both those which are intraspecifically variable,

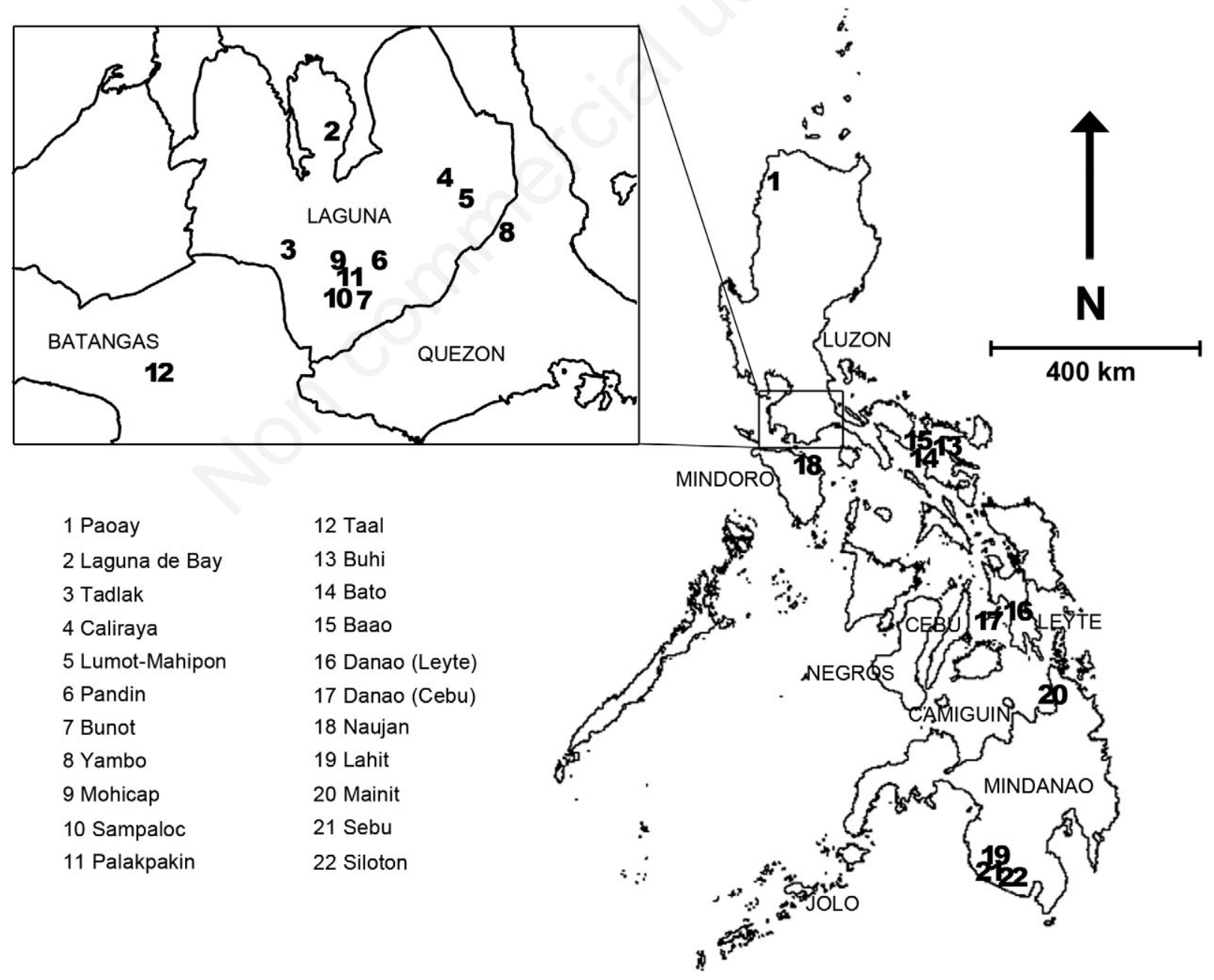

Fig. 1. Map of the Philippine archipelago showing the location of the 22 lakes sampled for this study. 
and those which are not) were coded as unordered, and given a weight of one. In the unscaled run, all characters with intraspecific variation (chars 1, 4, 8-10, 12, 16, and 18 ), as well as some fixed characters with serially homologous encaptive states (chars 2) were coded as ordered, and all characters were given a weight of one. In the scaled analysis, characters $1,2,4,8-10,12,16$, and 18 were coded as ordered; the fixed characters 2, 3, 5-7, 11, 13-15 and 17 were given a weight of 2 , and polymorphic characters were given a weight of one. In tree building, the $i e$ command was applied to produce trees by implicit enumeration, thus the results are in certain to be trees with shortest length. In the analysis of character transformations and editing of the trees we used WinClada (Nixon, 1999-2002).

Specimens were deposited in the Museum and Institute of Zoology (MIZ), Warsaw, Poland, and the University of Santo Tomas Zooplankton Reference Collection (USTZRC), Manila, Philippines.

\section{RESULTS}

\section{Taxonomic account}

\section{Order Cyclopoida G. O. Sars, 1913 \\ Family Cyclopidae Rafinesque, 1815 \\ Subfamily Cyclopinae Rafinesque, 1815 \\ Genus Mesocyclops G. O. Sars, 1914 \\ Mesocyclops augusti n. sp.}

Types: holotype, adult female dissected on two slides (MIZ:5/2013/1), Philippines, Mindanao, lake Siloton, $06^{\circ} 13.55^{\prime} \mathrm{N}, 124^{\circ} 43.85^{\prime} \mathrm{E}$, leg R.D.S. Papa, 27 Oct. 2006. For the physical characteristics of lake Siloton see Supplementary Material A. Paratype, one adult female (USTZRC: 0068) from the same locality as the holotype.

Other material: Vietnam, Vĩnh Púc province, Vĩnh Yên $21^{\circ} 18^{\prime} \mathrm{N}, 105^{\circ} 36^{\prime} \mathrm{E}$, lake Vac, leg. N.S. Vu \& Y.T. Nguyen, 10 Jul. 1996, two adult females (MIZ:5/2013/2; MIZ:5/2013/3), two adult males (MIZ:5/2013/4; MIZ:5/2013/5), one CV female (MIZ:5/2013/6).

Comparative material examined: $M$. affinis Van de Velde, 1987 [AFFI]: Indonesia, Java, Bogor Botanical Garden $06^{\circ} 37^{\prime} \mathrm{S} 106^{\circ} 48^{\prime} \mathrm{E}$, big lake, leg. M. \& R. Hołyńscy, 30 Sep. 1988, one female (ㅇ-1, collection of M.H.).

M. dissimilis Defaye et Kawabata, 1993 [DISS]: Japan, Honshu, lake Biwa: pelagic, North-basin $35^{\circ} 10^{\prime} \mathrm{N}$ $136^{\circ} 00^{\prime}$ E, leg. K. Kawabata, 27 Jul. 1995, three females ( $\left(9-1,2,3\right.$ collection of M.H.) and three males ( $\partial^{\lambda}-1,2,3$ collection of M.H.); littoral, South-basin $35^{\circ} 03^{\prime} \mathrm{N} 135^{\circ} 53^{\prime} \mathrm{E}$, leg. T. Ishida, 22 May 1988, four females (ㅇ-1,2,3,4, collection of M.H.). China, Jiangsu, Nanjing $32^{\circ} 02^{\prime} \mathrm{N}$ $118^{\circ} 46^{\prime}$ E, leg. G. Xiaoming, Aug. 1995, one female (MIZ:5/2013/7).
M. francisci Holynska, 2000 [FRAN]: Malaysia, Melaka, Ayer Keroh (12 km N Melaka) $02^{\circ} 18^{\prime} \mathrm{N}$ $102^{\circ} 15^{\prime} \mathrm{E}$, pond shore, leg. M. \& R. Hołyńscy 19 Sep. 1988, female holotype (MIZ:4644). Indonesia, Sumatra, Collectio Dadayana, III 282, 1 female paratype (MIZ:4646).

M. friendorum Holynska, 2000 [FRIE]: Indonesia, Celebes, Tambolang (2 km W Rantepao) 02 $59^{\prime} \mathrm{S}$ $119^{\circ} 53$ ', ricefield, leg. R. \& M. Hołyńscy, 8 Oct. 1988, female holotype, (MIZ:4647), and female paratype (MIZ:4648).

M. geminus Holynska, 2000 [GEMI]: Indonesia, Borneo, Mahakam river valley, Long Iram $00^{\circ} 02^{\prime} \mathrm{S} 115^{\circ} 37^{\prime}$, shallow pool in stream bed, leg. M. \& R. Hołyńscy, 23 May 1989, female holotype (MIZ:4651).

M. ogunnus Onabamiro, 1957 [OGUN]: Taiwan: Pingtung County, Jiuru Township, abandoned fishfarm [PTjr10]. Leg. K-S Tsai, 28 Jun. 2011, one female (MIZ:5/2013/8); Tainan City, Xinying Dist., fishfarm [TNsy06], leg. K-S. Tsai 01 May 2011, one female (MIZ: 5/2013/9). India, Chennai(?), leg. A. Zehra, one female (MIZ:5/2013/10).

M. parentium Holynska, 1997 [PARE]: India, Kerala, Chalakudy $10^{\circ} 18^{\prime} \mathrm{N} 76^{\circ} 22^{\prime} \mathrm{E}$, marsh, leg. S. George, 2 Sep. 1992, female holotype (MIZ:4618).

M. roberti Holynska et Stoch, 2012 [ROBE]: South Pacific, Wallis Island, Lac Lanutuli $13^{\circ} 19^{\prime} \mathrm{S} 176^{\circ} 13^{\prime} \mathrm{W}$, [18], leg. R. Schabetsberger \& G. Drozdowski, 2 Nov. 2004, one female paratype (MIZ:300003).

M. thermocyclopoides Harada, 1931 [THER]: Indonesia, Sumatra, Musi river, main stream, 14 Jan. 1976, Mizuno coll. 872, one female (-1, MIZ:5/2013/11); Java, Telagwarna, near Chibodus, 17 Dec. 1975, Mizuno Coll. 901. one female (㕜-2, MIZ:5/2013/12).

M. woutersi Van de Velde, 1987 [WOUT]: Australia, Queensland, Mount Isa $20^{\circ} 43^{\prime} \mathrm{N} 139^{\circ} 29^{\prime} \mathrm{E}$, M62, Fisher/Formax, 24 Feb. 1999, one female (-1 MIZ:5/2013/13). Taiwan, Pingtung county, Wutai township, artificial pool [PTwt03], leg. K-S Tsai, 16 Aug. 2011, two females (MIZ:5/2013/14, MIZ:5/2013/15).

Etymology: the species is named in honor of Associate Professor Augustus C. Mamaril Sr. of the University of the Philippines-Diliman, who is considered to be the foremost Filipino zooplanktologist.

Female (unless otherwise stated description refers to the holotype): body length $1080 \mu \mathrm{m}$ (paratype). Pediger 5 (Fig. 2A, 2C, 2D) laterally pilose, dorsally naked except for two medial and two posterolateral hair-sensilla. Genital double-somite 1.18 times as long as wide, naked (Fig. 2A). Six circular pores (Fig. 2D) posteriorly to leg 6 on laterodorsal surface of somite (paratype). Seminal receptacle (Fig. 2B) with wide lateral arms, anterior margin sinuate in middle, posterior sac large. Copulatory pore horseshoe-shaped, copulatory duct strongly curved, long. 


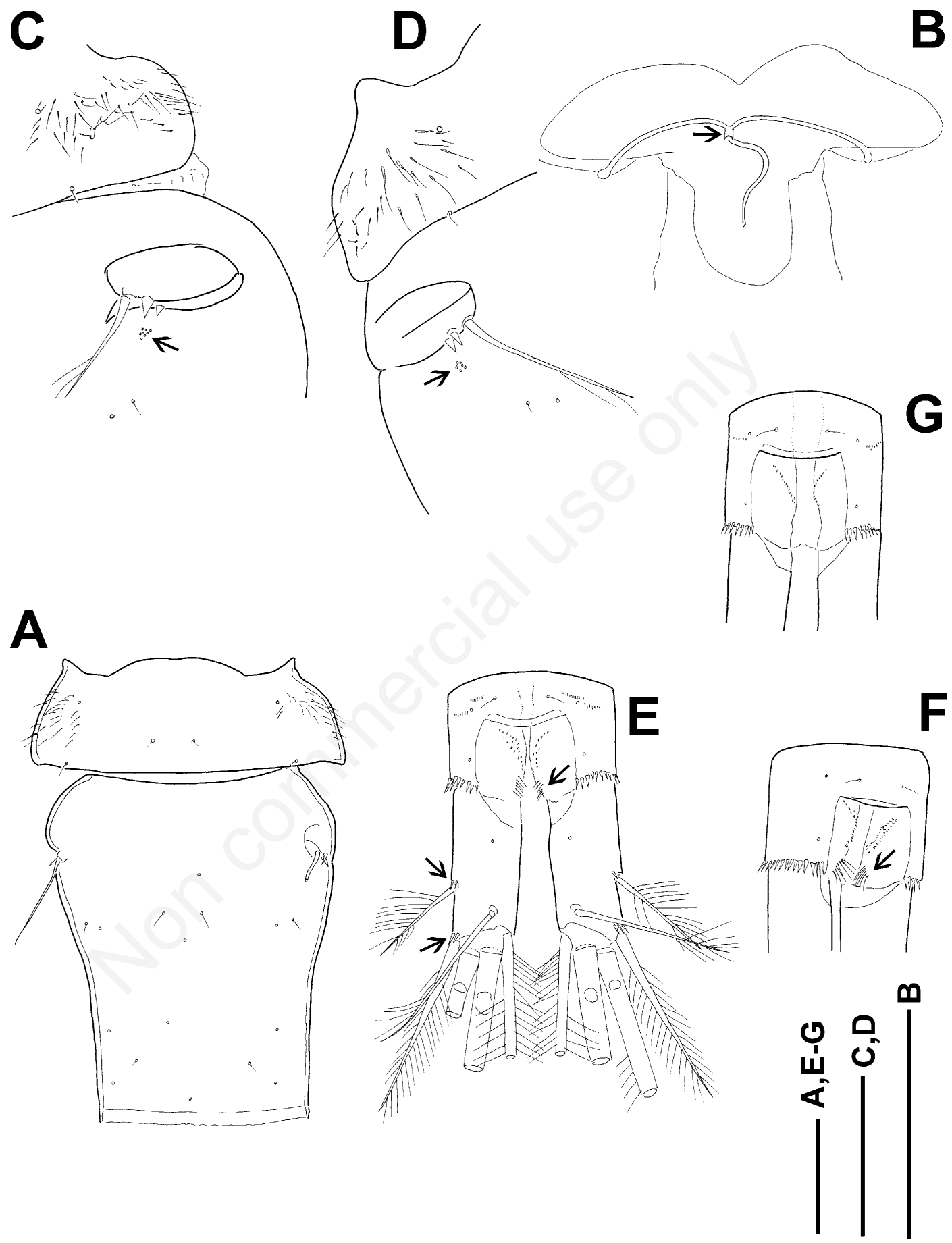

Fig. 2. A-F) Mesocyclops augusti n. sp., female; G) Mesocyclops dissimilis Defaye et Kawabata, 1993, female (L. Biwa, Japan). A) pediger 5 and genital double-somite, dorsal (Mindanao), holotype; B) seminal receptacle (Mindanao), paratype (arrow points to joint-canal); C) pediger 5 and genital double-somite, pores next to leg 6 (Vietnam), MIZ:5/2013/3 (arrow points to eight circular pores); D) pediger 5 and genital double-somite, pores next to leg 6 (Mindanao), paratype (arrow points to six circular pores); E) anal somite and caudal rami, dorsal (Mindanao), holotype (arrows point to long spinules in the hindgut, and spinules at the insertion of caudal setae II and III); F) anal somite, laterodorsal (Vietnam), MIZ:5/2013/3 (arrow points to long spinules in the hindgut); G) anal somite, dorsal, ㅇ-3. Scale bars: $50 \mu \mathrm{m}$. 
Single circular pore posterior to copulatory pore in female from Vietnam. Transverse canal-like structures meet anteriorly to copulatory pore at obtuse angle, forming jointcanal (Fig. 2B, arrowed). Hindgut (proctodeum) with oblique field of short spinules, and 1-1 row of long spinules near anterior margin of caudal rami (Fig. 2E and 2F, arrowed). Spinules form continuous row on posterior margin of anal somite. Caudal rami (Fig. 2E) 2.52 times as long as wide, without medial hair. Spinules present at insertion of lateral (II) and lateralmost terminal (III) caudal setae. Lateral caudal seta 0.62 times as long as caudal ramus, inserted at distance of 0.41 length measured from posteriormost end of ramus. Dorsal caudal (VII) seta as long as lateralmost terminal (III) caudal seta. Relative length of terminal caudal setae from medialmost (VI) to lateralmost (III): 2.82, 6.64, 4.19, 1.0. Longest terminal (V) caudal seta 1.4 times as long as urosome.

Antennule 17-segmented, with armature formula: 8, $4,2,6,4,1+$ seta transformed to short spine (sp), 2, 1, 1, $0,1,1+$ aesthetasc (ae), $0,1,2,2+a e, 7+a e$. Distal two terminal segments with finely serrate hyaline membrane, that on segment 17 extending beyond insertion of medial seta and bearing one large notch (Fig. 3B, arrowed). Small spinules present on anterior surface of segments 1, 4-5 and 7-13 (Fig. 3A, arrowed). Antenna composed of coxobasis and three-segmented endopodite, with three, one, seven and seven setae, respectively. Caudal surface of antennal coxobasis (Fig. 3C) ornamented with long lateral spinules near base (group a), oblique row of robust spinules (10) near lateral margin (group b), oblique row/field of fine spinules starting near midlength of medial margin (group c), fine spinules on medial margin near base (group d), longitudinal row of spinules (17) of slightly increasing size next to lateral margin (group e), group of small spinules near insertion of medial setae (group f), and few small spinules next to distal margin (group g). Frontal surface adorned with long longitudinal row of small spinules (29) next to lateral margin, and transverse row of fine spinules near base.

Integumental perforation pattern of rostrum as in Fig. 3D. Labrum with 13 teeths on distal edge, lateral lobes smooth (Fig. 3E, arrowed), distal fringe-hair arranged in arc. Shorter spinules (Fig. 3E and 3F, arrowed) present on both right and left side of labrum, anteriorly to fringehair. Epistoma (longitudinal medial hump between labrum and rostrum) pilose (Fig. 3E), hair also present laterally to epistoma. Vertical cleft between epistoma and rostrum pilose (verified in paratype from Mindanao and females from Vietnam) resembling that in M. microlasius. Mandible (Fig. 4A and 4B) with palp bearing two long and one short setae. Three groups of spinules present on anterior surface of gnathobase near mandibulary palp. Maxillule armature as common in genus, palp naked (Fig. 4C). Proximalmost seta of maxillulary palp and three setae of lateral lobe without long setules. Maxilla (Fig. 4D and 4E) segmentation and setation as usual in genus. Row(s) of spinules (Fig. 4E, arrowed) present on frontal surface of coxopodite. Maxilliped (Fig. 5A) four-segmented with three, two, one, and three setae, respectively. Lateral seta on terminal segment shorter than $1 / 4$ length of median seta. No surface ornamentation on frontal surface of syncoxopodite. Caudal surface of basipodite (segment 2) with spinules arranged into two groups (not shown in Fig. 5A), frontal side bearing long and thin spinules near medial margin. First endopodal segment (segment 3 ) with few short spinules next to distal margin.

Armature formula of swimming legs as in Tab. 2. P1 basipodite (Fig. 5B) lacking medial spine/seta. Medial expansion of basipodite apically pilose in P1-P4. In P4 additional row of long hairs present on caudal surface near medial margin of basipodite (Fig. 5C, arrowed). Long spinules appear on frontal surface of basipodite near lateral margin in P1-P4. Couplers of P1-P4 bare on frontal and caudal surfaces. Outgrowths (Fig. 5C, arrowed) small ( $c a$. as long as wide) and acute on distal margin of $\mathrm{P} 4$ coupler. Caudal surface of $\mathrm{P} 4$ coxopodite bearing intermittent row of spinules (11) along distal margin, group of elongate spinules at laterodistal angle, robust spinules of unequal size in middle near proximal margin of segment, and long hair in lateral part. Lateral margin of $\mathrm{P} 4$ first segment of exopodite (exp1) with hair, exp2 and exp3 with spinules (Fig. 5C). P4 third segment of endopodite (enp3) (Fig. 5C) 2.8 times as long as wide, terminal spines subequal, outer margin of medial spine with many (9) spinules. P5 (Fig. 5D) as typical of genus.

Tab. 2. Armature of legs 1-4 in Mesocyclops augusti n. sp.

\begin{tabular}{lcccc}
\hline Leg & Coxopodite & Basipodite & Exopodite & Endopodite \\
\hline 1 & $0-1$ & $1-0$ & I-1; I-1; I-I,2-2 & $0-1 ; 0-2 ; 1-$ I, $1-3$ \\
2 & $0-1$ & $1-0$ & I-1; I-1; I-II,1-3 & $0-1 ; 0-2 ; 1-$ I,1-3 \\
3 & $0-1$ & $1-0$ & I-1; I-1; I-II,1-3 & $0-1 ; 0-2 ; 1-I, 1-3$ \\
4 & $0-1$ & $1-0$ & I-1; I-1; I-II,1-3 & $0-1 ; 0-2 ; 1-$ II-2 \\
\hline
\end{tabular}

Roman numerals denote spines, while Arabic denote setae. The armature on the lateral margin of any segment is given first, followed by the elements on the apical and medial margins. 
Male (Vietnam): body length 700-730 $\mu \mathrm{m}$; cephalothorax, length/width: 1.1-1.2; prosome length/urosome length: 1.6-1.8. Pediger 5 (Fig. 6A) with sparse short lateral hairs, dorsal surface bare. Hindgut without surface ornamentation. Posterior margin of anal somite with continuous row of spinules. Caudal rami 2.2-2.5 times as long as wide, no medial hair. Spinules present at insertion of lateral (II) and lateralmost terminal (III) cau- dal setae. Lateral caudal seta 0.5-0.6 times as long as caudal ramus, inserted at distance of 0.42 length measured from posteriormost end of ramus. Dorsal (VII) caudal seta 1.2 times as long as lateralmost terminal (III) caudal seta. Relative length of terminal caudal setae from medialmost (VI) to lateralmost (III): 2.7, 5.2, 3.1-3.3, 1.0. Longest terminal $(\mathrm{V})$ caudal seta as long as urosome.

Antennule 16-segmented, armature as in M. microla-

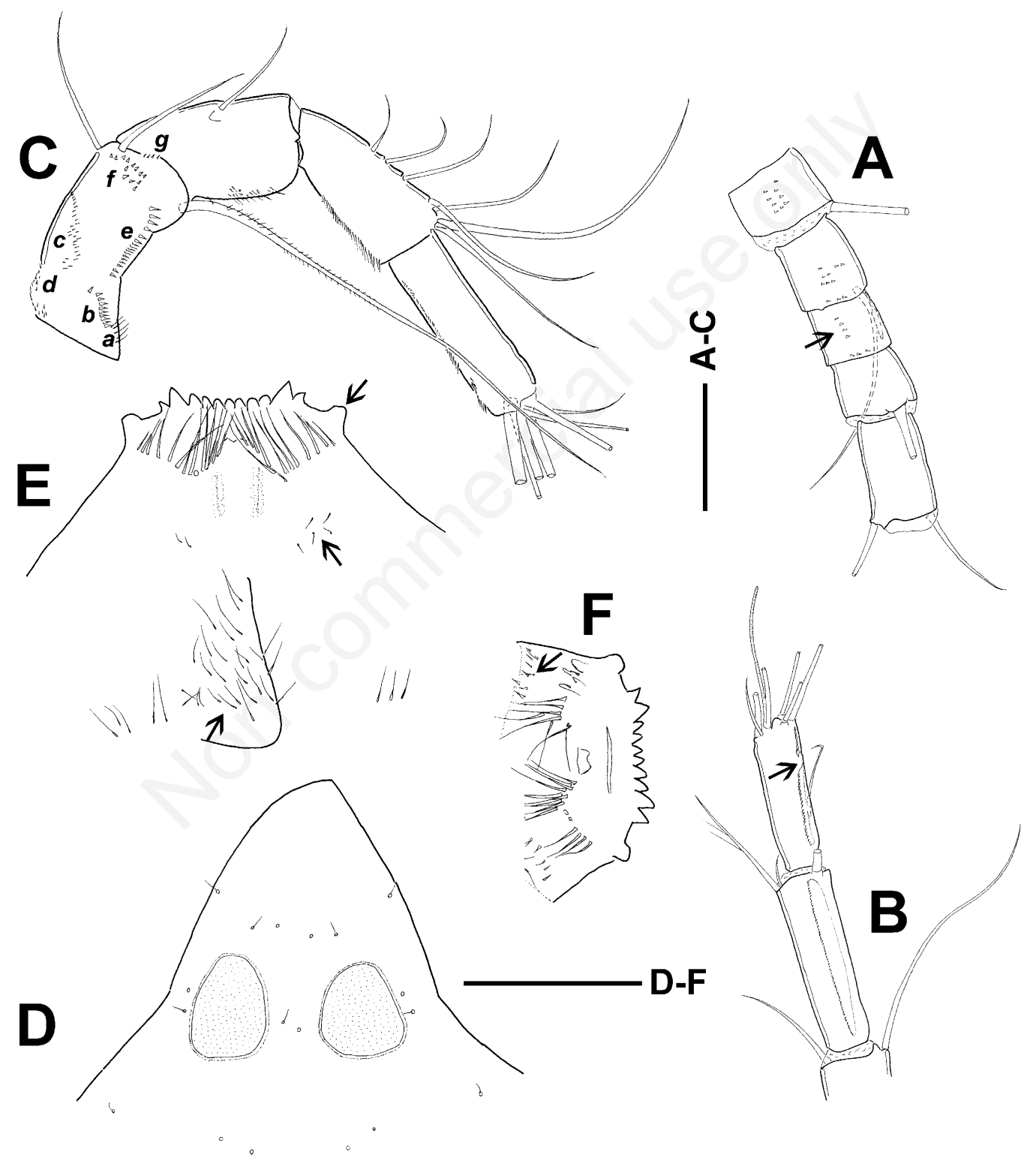

Fig. 3. Mesocyclops augusti n. sp., female: antennule, anterior (Mindanao). A-D) show holotype, E) shows paratype, and F) shows Vietnam MIZ:5/2013/3. A) segments 11-15 (arrow indicates small spinules on segment 14); B) segments 16-17 (arrow indicates large notch); C) antenna, caudal (Mindanao) (a-g, groups of spinules); D) rostrum (Mindanao); E) labrum and epistoma, ventral (Mindanao) (arrows point to smooth lateral lobe of labrum, short spinules on labrum, and hairy epistoma); F) labrum, ventral (Vietnam) (arrow points to short spinules). Scale bars: $50 \mu \mathrm{m}$. 
sius. Spinules present on first antennular segment only. Antenna enp2 with six setae. Caudal surface ornamentation of antennal coxobasis (Fig. 6C) similar to that in female in Vietnam, but differs from female in Mindanao in absence of spinules next to distal margin. Labrum bearing distal fringe hair only, epistoma and vertical cleft bare. Longitudinal rows of spinules absent on frontal surface of maxillary coxopodite. Mandible, maxillule and maxilliped as in female. Armature formula of P1-P4 as in female. Long spinules absent on laterofrontal surface of basipodite in P1-P4. Outgrowths small and acute on distal margin of $\mathrm{P} 4$ coupler. Caudal surface ornamentation of $\mathrm{P} 4$ coxopodite (Fig. 5E) similar to that in female, but lateral hair restricted to one row in middle. Medial expansion of P4 basipodite apically pilose, oblique row of hairs also present on caudal surface of segment. Lateral margin of P4 exopodal segments with small spinules. P4 enp3 2.7-3.0 times as long as wide. Medial terminal spine 0.9 times as long as lateral spine, longer (lateral) terminal spine 0.9 times as long as segment. Lateral margin of medial spine bearing many spinules. P6 flap (Fig. $6 \mathrm{~A}$ ) with several rows of small spinules, mediodistal angle with small teeth. P6 (Fig. 6D) median seta subequal or slightly shorter than medial spine, lateral seta 2.1 times as long as medial spine.

\section{Intraspecific variation}

Variation of the morphometric characters is shown in Tab. 3. Six (single female verified in Mindanao) or eight (two females in Vietnam) pores present posteriorly to P6. Female genital structures: transverse canal-like structures meet at obtuse (Mindanao) or acute (Vietnam) angle. Surface ornamentation of antennule: spinules present on segments 1, 4-5, 7-13 (Mindanao), or 1, 4-5, 7-14 (Vietnam). Spinules present (Mindanao), or absent (Vietnam) next to distal margin of antennal coxobasis (group g; Fig. 3C). Long spinules present on frontal surface of basipodite near lateral margin in P1-P4 (Mindanao) or in P1-P3 (Vietnam).

Mesocyclops microlasius Kiefer, 1981

Mesocyclops microlasius Kiefer (1981); Hołyńska (2000); Hołyńska et al. (2003); Tuyor and Baay (2001).

Mesocyclops sp.: Aquino et al. (2008)

Material examined: Philippines, Luzon, lake Paoay $18^{\circ} 7.3^{\prime} \mathrm{N} 120^{\circ} 32.4^{\prime} \mathrm{E}$, leg. R. Aquino, Apr.-Sep. 2006, 3 females (MIZ:5/2013/16, MIZ:5/2013/17, MIZ:5/2013/ 18), 3 males (MIZ:5/2013/19, MIZ:5/2013/20, MIZ:5/2013/21). For the physical characteristics of lake Paoay see Supplementary Material A.

Female (L. Paoay): body length $980 \mu \mathrm{m}$; cephalothorax, length/width: 1.2-1.4; prosome length/urosome length: 1.77-1.84; width of cephalothorax/width of genital double-somite: $2.5-2.9$. Pediger 5 (Fig. 7A) with lateral hair, dorsal surface naked. Genital double-somite 1.2-1.3 times as long as wide, naked, integumental perforation pattern shown in Fig. 7A and 7B. Seminal receptacle as in Fig. 7B, transverse duct-like structures meet anteriorly to horseshoe-shaped copulatory pore, forming joint-canal. Hindgut (proctodeum) bearing oblique/longitudinal field of spinules medially, and triangular field of small spinules more laterally near anterior margin of caudal rami (Fig. 7C, left arrowed). Posterior margin of anal somite with continuous row of spinules. Caudal rami (Fig. 7C) 2.42.8 times as long as wide. Short hair (Fig. 7C, right arrowed) present on medial margin in anterior half of rami. Spinules present at insertion of lateral (II) caudal setae in one of three females. Spinules present at insertion of lateralmost terminal (III) caudal setae in all specimens. Dorsal (VII) caudal seta 0.81 times as long as lateralmost terminal (III) caudal seta. Lateral (II) seta 0.51-0.63 times as long as caudal ramus, and inserted at distance of 0.410.43 length measured from posteriormost end of ramus. Relative length of terminal caudal setae from medialmost

Tab. 3. Variation of the morphometric characters in female of Mesocyclops augusti $\mathrm{n}$. sp.

\begin{tabular}{lcc}
\hline Morphometric characters & Mindanao & North Vietnam \\
\hline 1 & 1080 & $1010-1050$ \\
2 & 1.17 & 0.98 \\
3 & $1.16-1.18$ & $1.26-1.32$ \\
4 & 1.87 & $1.58-1.60$ \\
5 & 1.40 & 1.11 \\
6 & 2.80 & 3.50 \\
7 & $2.48-2.52$ & $3.4-3.5$ \\
8 & $0.58-0.62$ & 0.40 \\
9 & $0.39-0.41$ & 0.38 \\
10 & 0.97 & $1.17-1.21$ \\
11 & $2.84-3.12$ & $2.44-2.81$ \\
12 & 6.6 & 5.5 \\
13 & $4.19-4.31$ & $3.33-3.75$ \\
14 & $1.53-1.71$ & 1.86 \\
15 & $2.57-2.81$ & $2.97-3.35$ \\
16 & $0.97-0.99$ & $0.92-1.02$ \\
17 & $0.83-0.88$ & $0.92-0.94$ \\
18 & 1.23 & 1.45 \\
19 & 0.87 & 0.97 \\
\hline
\end{tabular}

1, body length in $\mu m ; 2$, cephalothorax, length/width; 3 , genital doublesomite, length/width; 4, length of prosome/length of urosome; 5 , length of longest terminal caudal seta/length urosome; 6 , width of cephalothorax /width of genital double-somite; 7, caudal ramus, length/width; 8, length of lateral caudal seta/length of caudal ramus; 9, distance of insertion of lateral caudal seta, measured from posterior end of ramus/length of caudal ramus; 10, caudal setae, dorsal/lateralmost; 11, terminal caudal setae, medialmost/lateralmost; 12, terminal caudal setae, inner median (longest)/lateralmost; 13, terminal caudal setae, outer median/lateralmost; 14, fourth leg, length of coxopodite seta/height of medial expansion of basipodite; 15, fourth leg endopodite 3, length/width; 16, fourth leg endopodite 3, medial terminal spine/lateral terminal spine; 17, fourth leg endopodite 3, length of longer terminal spine/length of segment; 18, fifth leg, length of apical seta/length of medial spine; 19, fifth leg, length of lateral seta/length of medial spine. 
(VI) to lateralmost (III): 2.4-2.8, 5.5-6.1, 3.9-4.1, 1.0. Longest terminal (V) caudal seta 1.2-1.4 times as long as urosome.

Armature formula of antennule as in M. augusti n. sp. Segments 1, 4-5, 7-13 adorned with spinules on anterior surface. Hyaline membrane of last antennulary segment with one large notch. Antenna enp2 with seven setae. Caudal surface ornamentation of antennal coxobasis as in Fig. 7E: spinules (11-14) distally increasing slightly in longitudinal row next to lateral margin (Fig. 7E, arrowed).
Frontal surface with long longitudinal row of spinules (24-27) near lateral margin.

Labrum (Fig. 7D) bearing distal fringe of hairs arranged in arc. Spinules/hair absent anteriorly to distal fringe hair (Fig. 3F where spinules are arrowed). Epistoma (longitudinal medial hump between labrum and rostrum) pilose (Fig. 7D, lower arrowed), hair also present laterally to epistoma. Vertical cleft between rostrum and epistoma pilose (Fig. 7D, upper arrowed). Segmentation and setation of mandible, maxillule, maxilla and maxil-

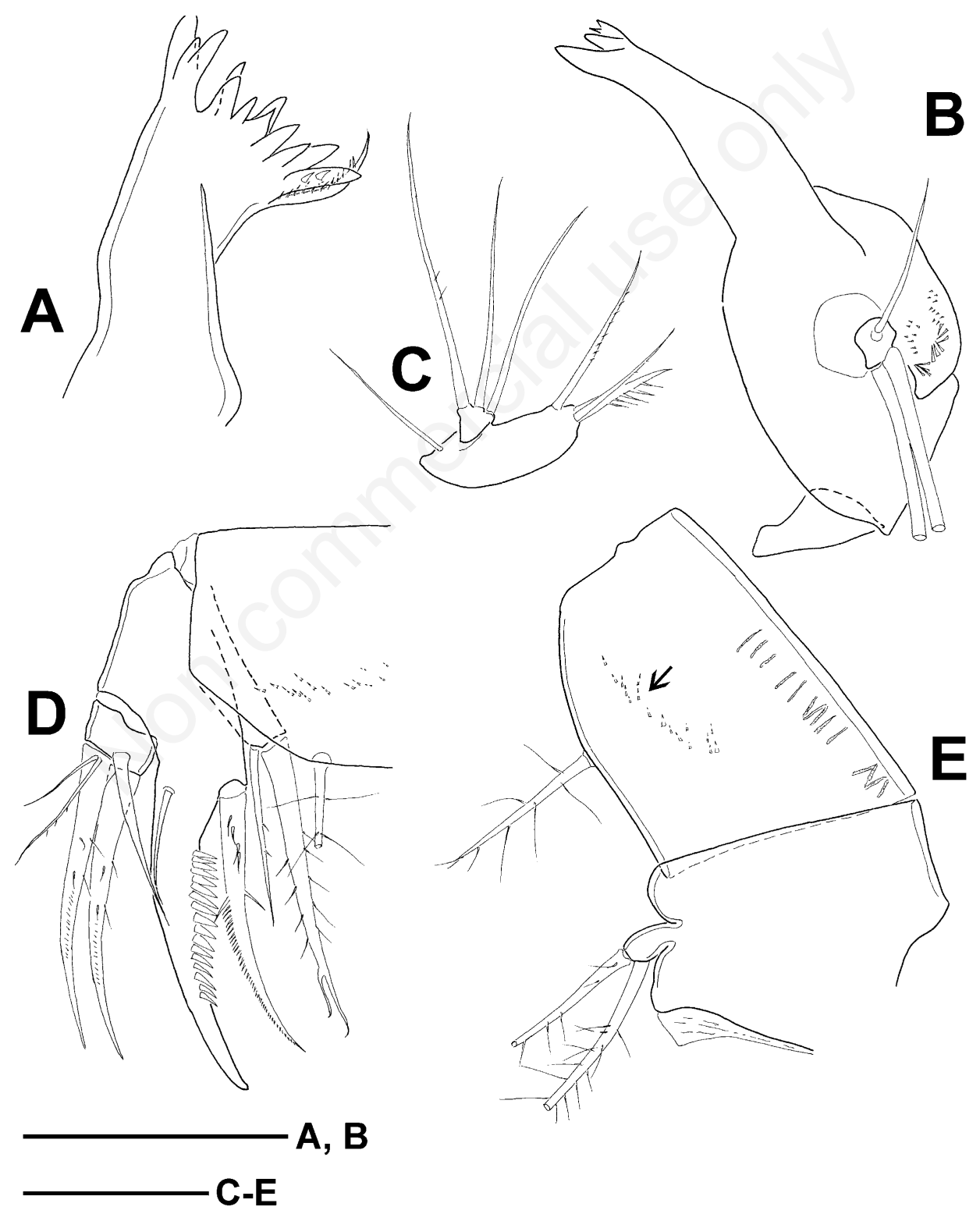

Fig. 4. Mesocyclops augusti n. sp., female (Mindanao). Except for A) showing paratype, all drawings show holotype. A and B) mandible; C) maxillulary palp; D-E) maxilla, caudal: D) distal part of coxopodite, basipodite and endopodite, and E) syncoxopodite (arrow indicates rows of spinules). Scale bars: $50 \mu \mathrm{m}$. 

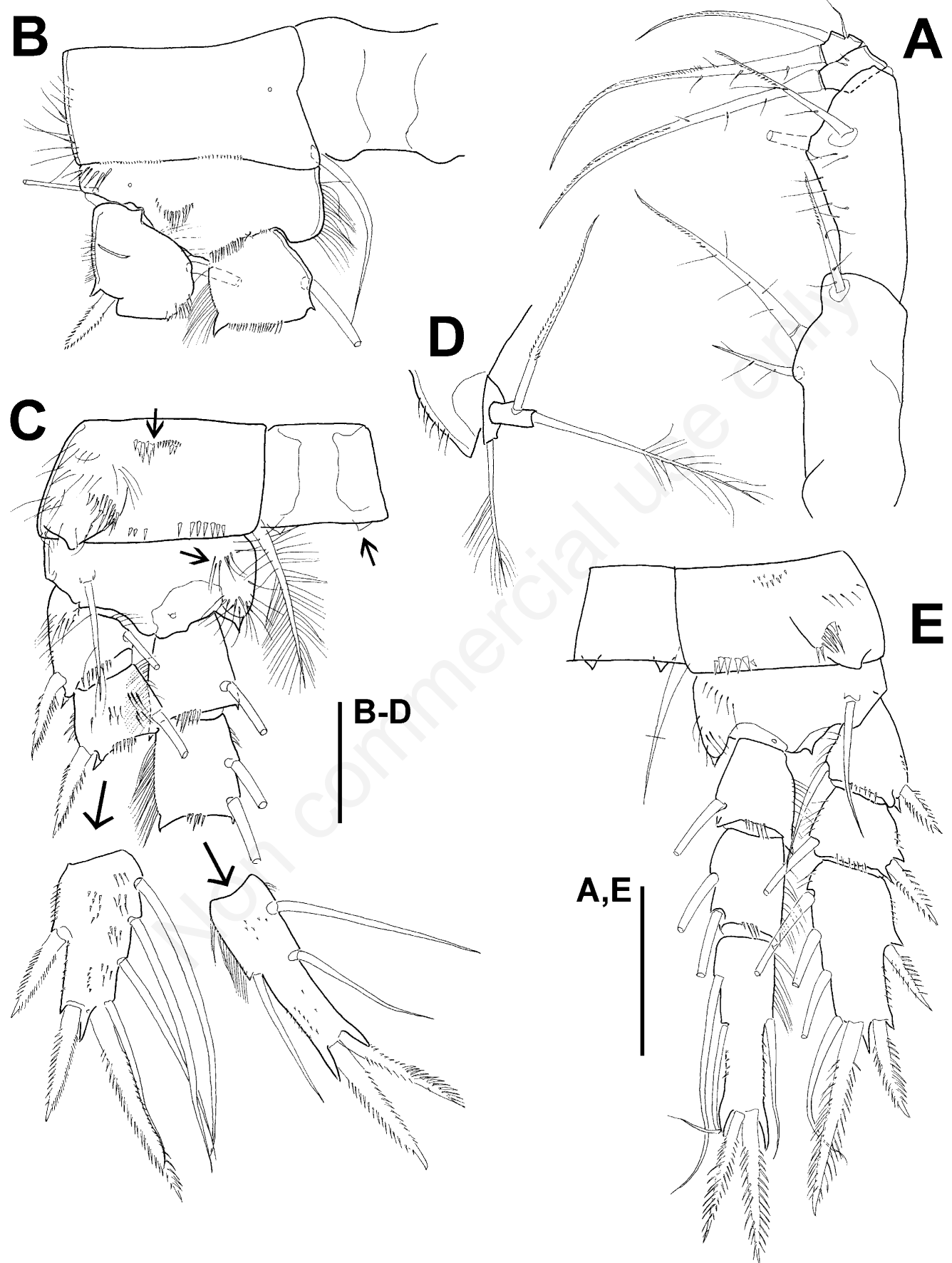

Fig. 5. Mesocyclops augusti n. sp.: female. A-C) show holotype, D) shows paratype, and E) shows Vietnam MIZ:5/2013/5. A) maxilliped, frontal, medial seta on basipodite broken off; B) leg 1 protopodite, and first exo- and endopodal segment, frontal; C) leg 4, caudal (short arrows indicate small outgrowths of coupler, spinules of unequal size in proximal row of coxopodite, and row of long hair on basipodite, while long arrows point to terminal segments of exo- and endopodite); D) leg 5. male (Vietnam); E) leg 4 caudal, distal half of coxal seta broken off. Scale bars: $50 \mu \mathrm{m}$. 
liped as usual in genus (Figs. 4A-E and 5A). Three groups of spinules present on anterior surface of gnathobase near mandibulary palp. Maxillulary palp bare. Row(s) of robust spinules present on frontal surface of maxillary coxopodite, similarly to that in M. augusti sp. nov, (Fig. 4E, arrowed).

Armature formula of P1-P4 as in M. augusti n. sp. (Tab. 2). Basipodite of $\mathrm{P} 1$ lacking medial spine. Medial expansion of basipodite apically pilose in P1-P4. Additional row of long medial hair present on caudal surface of segment in P4 (Fig. 8A, arrowed). Couplers of P1-P4 bare on caudal and frontal surfaces. Outgrowths small and acute on distal margin of $\mathrm{P} 4$ coupler. Caudal surface ornamentation of $\mathrm{P} 4$ coxopodite (Fig. 8A) comprising: robust spinules (7-11) in continuous or intermittent row next to distal margin, group of long spinules at laterodistal angle, row of spinules of unequal size in middle near proximal margin, and hair in lateral part. Lateral margin of P4 exopodal segments with long hair (Fig. 8A). P4 enp3 2.6-3.0 times as long as wide; of terminal spines, medial one 1.0-1.2 times as long as lateral spine, and 0.76-
0.88 times as long as segment. Lateral margin of medial terminal spine of P4 enp3 with 8-15 small spinules. P5 (Fig. 7F) typical of genus, segment 2 with long apical seta almost reaching posterior margin of genital doublesomite, and 1.4-1.8 times as long as medial spine. Lateral seta on first segment $0.83-1.35$ times as long as medial spine.

Male (L. Paoay): body length 625-635 $\mu \mathrm{m}$, prosome length/urosome length: 1.74-1.77. Pediger 5 with few hairs on lateral surface, dorsal surface naked. Hindgut (proctodeum) (Fig. 8B) bearing oblique/longitudinal rows of hair-like spinules and triangular field of small spinules more laterally near anterior margin of caudal rami. Posterior margin of anal somite with continuous row of spinules. Caudal rami 2.3-2.4 times as long as wide, with group of hair near anterior end of rami. Robust spinules present at insertion of lateral (II) and lateralmost terminal (III) caudal setae. Lateral seta 0.71-0.76 times as long as caudal ramus, and inserted at distance of 0.42-0.45 length measured from posteriormost end of ramus. Dorsal (VII) caudal seta 0.9-1.1 times as long as lateralmost terminal

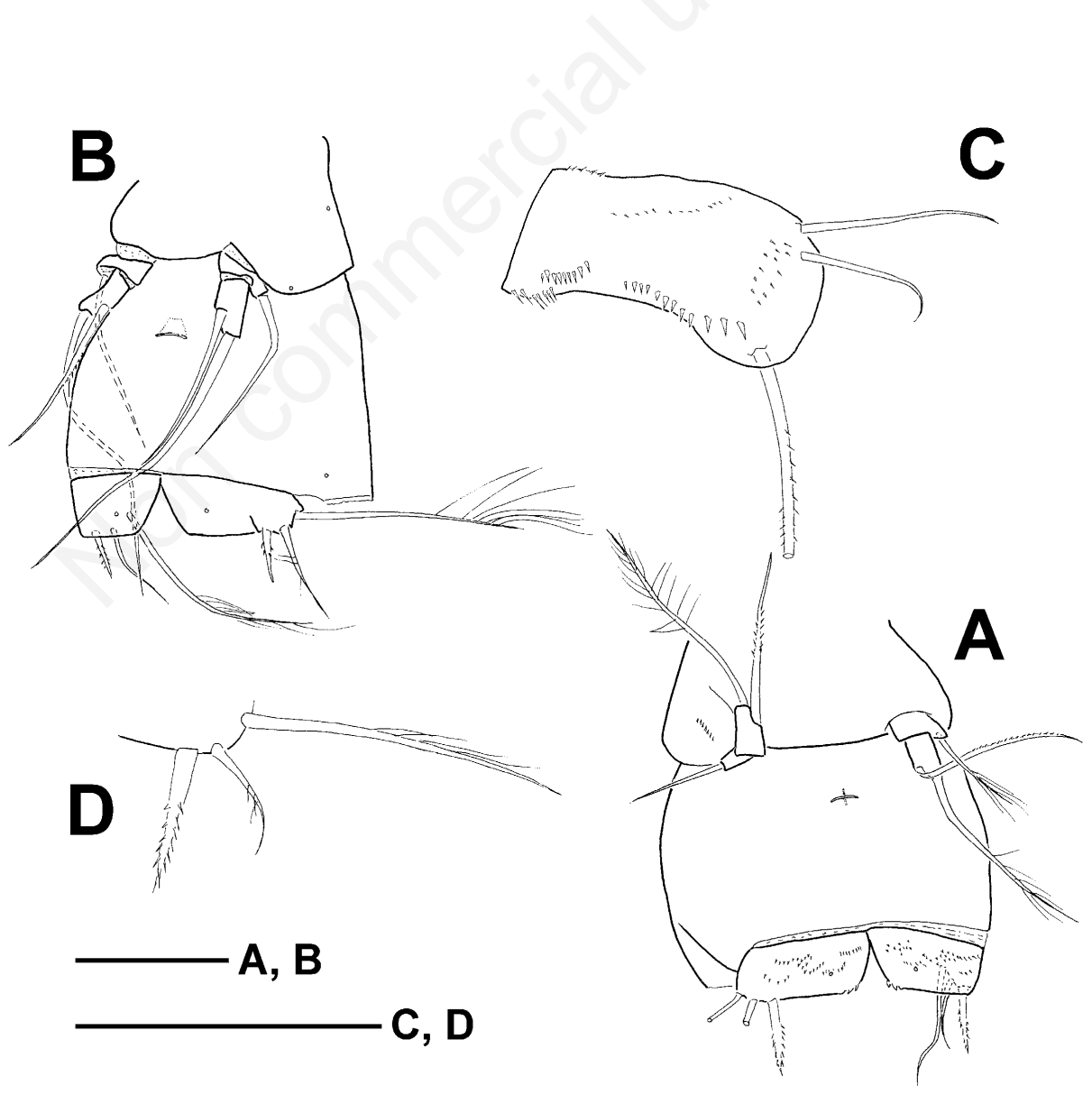

Fig. 6. A, C, D) Mesocyclops augusti n. sp., male (Vietnam); B) Mesocyclops dissimilis Defaye et Kawabata, 1993, male (L. Biwa, Japan). A) Pediger 5 and genital segment, ventral, MIZ:5/2013/4; B) pediger 5 and genital segment, lateroventral, ô-3; C) antennal coxobasis, caudal, MIZ:5/2013/5; D) leg 6, MIZ:5/2013/5. Scale bars: $50 \mu \mathrm{m}$. 
(III) caudal seta. Relative length of terminal caudal setae from medialmost (VI) to lateralmost (III): 2.4-2.5, 5.35.7, 3.7-4.0, 1.0. Longest terminal (V) caudal seta 1.1-1.3 times as long as urosome.

Antennule (Fig. 9A-D) 16-segmented, with incomplete subdivision of compound apical segment, with armature formula: 8+3ae, 4, 2, 2+ae, 2, 2, 2, 2, 1+sp+ae; 2, 2, 2, $2+\mathrm{ae}, 2,1+\mathrm{ae},(4+\mathrm{ae}, 7+\mathrm{ae})$. Plate-like structures with pore (one large plate on segment 14 and two smaller ones on segment 15) and short conical elements (one on segment 14 and 15 each) present at distal geniculation. Smooth hyaline membrane present in proximal half of compound apical segment. Spinules present on anterior surface of segment 1 only.

Antenna enp2 with six setae. Caudal surface ornamentation of antennal coxobasis (Fig. 9E) similar to that in female, but number of spinules less in particular groups. On frontal surface 18-20 spinules present in longitudinal row next to lateral margin.

Labrum with 10 distal teeth. Except for fringe hair no ornamentation on labrum, epistoma and vertical cleft naked. Segmentation and setation of mandible, maxillule, maxilla and maxilliped as in female. Spinules tiny or absent on frontal surface of maxillary coxopodite.

Armature formula of P1-P4 as in female. Couplers of P1-P4 naked on frontal and caudal surfaces. Medial pilosity of basipodite of P1-P4 as in female. Outgrowths small and acute on distal margin of P4 coupler. Caudal surface ornamentation of $\mathrm{P} 4$ coxopodite (Fig. 8C) similar to that in female but lateral pilosity scarce. Spinules/hair present on lateral margin of second and third exopodal segment of P4, but much shorter than those in female (Fig. $8 \mathrm{~A}$ and $8 \mathrm{C}$ ). P4 enp3 2.7-2.8 times as long as wide. Medial terminal spine of $\mathrm{P} 4$ enp $3 \mathrm{ca}$. 1.1 times as long as lateral spine, and 0.81-0.95 times as long as segment. Lateral margin of medial terminal spine with many fine spinules. P6 flap (Fig. 8D) with few transverse rows of spinules, mediodistal angle with two small teeth. P6 median and lateral seta 1.0-1.2 and 2.5-2.7 times as long as medial spine, respectively.

\section{Comments}

This species was originally described from specimens collected from Manila (type locality; cement ponds) and Laguna de Bay during the Wallacea-expedition (Kiefer, 1981). It was later identified from samples collected in lake Sebu (Mindanao), which is the southernmost locality where it has been recorded (Tuyor and Baay, 2001). This is the first time that $M$. microlasius has been reported in northern Luzon, $c a .430 \mathrm{~km}$ from the type locality. Aquino et al. (2008) listed a Mesocyclops sp. from lake Paoay but did not identify to species level. The specimen examined here is part of the samples analysed in the aforementioned study.
For an analysis of the phylogenetic relationships of $M$. microlasius see the Discussion.

\section{Geographic distribution of limnetic Cyclopidae in the Philippines}

A total of 4 species of Mesocyclops, 3 of Thermocyclops, and 1 species each of Microcyclops and Paracyclops were identified (Tab. 4, Fig. 10). Two species ( $T$. taihokuensis and $M$. augusti n. sp.) are new records for the Philippines. There was only one male specimen each for Microcyclops and Paracyclops. The identification of Microcyclops sp. to species level was not done due to the absence of a key for male Microcyclops. Thermocyclops crassus is the most widely distributed species, occurring in 16 lakes found across all five islands followed by Mesocyclops thermocyclopoides and T. taihokuensis, both occurring in six lakes each. Thermocyclops taihokuensis, however, seems to be restricted to Luzon island, while $M$. thermocyclopoides, which occurs mostly in Luzon, was also found in Mindoro island. The endemic M. microlasius - which was first collected from the Philippines 80 years ago during the Wallacea-expedition - was found in lake Paoay (northern Luzon). Thermocyclops decipiens was only found in three lakes within one small locality in Southwest Mindanao. Paracyclops fimbriatus is hereby reported for the first time in lake Mainit together with $M i$ crocyclops sp. and Mesocyclops sp. (Mindanao island).

\section{DISCUSSION}

\section{Notes on morphology and phylogenetic relationships of Mesocyclops augusti $\mathrm{n}$. sp.}

The unique surface ornamentation of the hindgut (oblique field of short spinules, and row of long spinules more posteriorly) distinguishes $M$. augusti $\mathrm{n}$. sp. from all the other Mesocyclops species. In many cyclopine and eucyclopine genera (e.g. Acanthocyclops, Megacyclops, Diacyclops, Eucyclops, Ectocyclops, Macrocyclops and

Tab. 4. Cyclopid species identified from the limnetic zone of different freshwater lakes in the Philippines (cf. Fig. 1 and Supplementary Material A).

\begin{tabular}{lc}
\hline Cyclopid species & Lake \\
\hline Mesocyclops microlasius Kiefer, 1981* & 1 \\
M. thermocyclopoides Harada, 1931 & $2,4,5,11,13,18$ \\
Mesocyclops sp. & 20 \\
Mesocyclops augusti n. sp. & 22 \\
Microcyclops sp. (male only) & 20 \\
Paracyclops fimbriatus (Fischer, 1853) & 20 \\
Thermocyclops crassus (Fischer, 1853) & $1-3,7-14,16-20$ \\
T. decipiens (Kiefer 1929) & $19,21,22$ \\
T. taihokuensis (Harada, 1931) & \\
\hline
\end{tabular}

"Endemic species; ${ }^{\circ}$ new record. 
Paracyclops) spinules or hair are frequently present in the hindgut (proctodeum), therefore the pilose/spinulose proctodeum supposedly is an ancestral state in Cyclopinae. Hołyńska (2006b) reported surface ornamentation of the hindgut in only few, distantly related Mesocyclops taxa [M. dissimilis (East Asia) - small spinules; M. annulatus (Wierzejski, 1892) (South America) - small spinules; and M. cuttacuttae Dumont et Maas, 1985 (Australia) - row of long hair-like spinules], yet we found this feature to be more common in the genus than previously thought. All members of the woutersi-complex (see definition further), as well as $M$. francisci, $M$. microlasius, $M$. geminus, $M$. ogunnus and sometimes M. pehpeiensis $\mathrm{Hu}, 1943$ have rows or oblique fields of spinules, though can be tiny and easy to overlook in the hindgut. The conspicuous surface ornamentation present in the Mindanao females from lake Siloton, also appears in two adults and one fifth copepodid stage (CV) female in lake Vac, North Vietnam. The Viet-

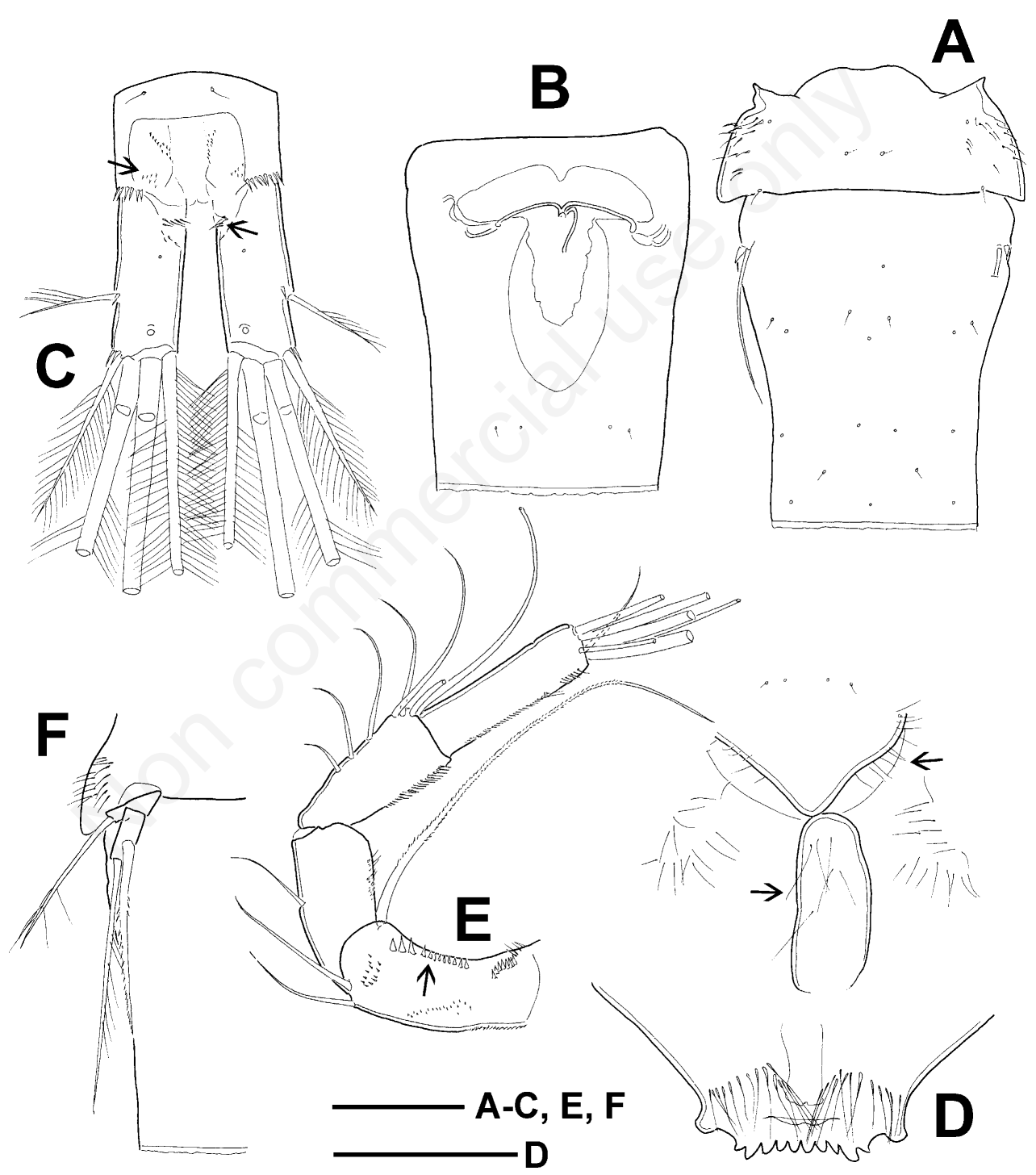

Fig. 7. Mesocyclops microlasius Kiefer, 1981, female (L. Paoay, Luzon). A, C, E) show MIZ:5/2013/16, B and F) show MIZ:5/2013/17, and D) shows MIZ:5/2013/18. A) Pediger 5 and genital double-somite, dorsal; B) genital double-somite, ventral; C) anal somite and caudal rami, dorsal (left arrow indicates triangular field of small spinules in hindgut, while right arrow indicates short hair on caudal ramus); D) rostrum, epistoma, and labrum (upper arrow points to hair in vertical cleft, while lower arrow points to hair on epistoma); E) antenna, caudal (arrow indicates longitudinal row of spinules); F) leg 5. Scale bars: $50 \mu \mathrm{m}$. 
namese and Mindanao specimens share several other characters as well, therefore we consider them to be conspecific. There are a few features, in which the North Vietnam and Mindanao females seem to be different (cf. intraspecific variation). Most of the qualitative characters differing in these distant populations, however, are intraspecifically variable in the close relatives [surface ornamentation of the antennule and antennal coxobasis (group g) varies within both $M$. dissimilis and $M$. woutersi; female genital structure, tranverse canal-like structures form acute or obtuse angle in $M$. woutersi; $\mathrm{P} 4$ basipodite, laterofrontal spinules present or absent in $M$. ogunnus]. Therefore those differences were given less importance. Nonetheless, with the exception of M. augusti n. sp. where the Vietnam and Mindanao females have eight and six pores, respectively, no polymophism was found in number of the pores posteriorly to P6 (cf. Supplementary Material C) in any taxon included in the present phylogenetic analysis.

It is especially difficult to interpret the morphometric differences (Mindanao 2우으, and North Vietnam 2우우). Comparisons of the pelagic and littoral populations of $M$. dissimilis in lake Biwa (Japan) revealed significant shifts in the body size and proportions such as the relative length of the leg segments (P4 enp3), caudal rami, and dorsal caudal seta (Hołyńska, 1997), which warned us about the cautious use of the morphometric traits in species identification. We lack strong evidence of a (sub)species-level separation, and the apparent morphological separation of the Mindanao and North Vietnam forms can only be confirmed by the examination of additional material. Also, the Mindanao and North Vietnam findings do not necessarily indicate disjunct distribution until faunistic information on the Philippines (e.g. the Sulu archipelago as a possible dispersal route), Borneo, and Indochinese peninsula are so fragmentary.

Mesocyclops augusti $\mathrm{n}$. sp. is closely related to the woutersi-complex coined and defined by Hołyńska (1997, 2000). The group was diagnosed by the characters of the antenna (enp 2 with seven setae; complex spinule ornamentation on the caudal surface of the coxobasis), female genital system (transverse ducts meet at acute angle), and surface ornamentation of $\mathrm{P} 4$ coxopodite (spinules of conspicuously different size near proximal margin), and it comprised M. woutersi, M. dissimilis, M. parentium and M. friendorum. Mesocyclops francisci was hypothesised as the sister of the woutersi-complex. A phylogenetic analysis (Hołyńska, 2006b) that included all Mesocyclops species (71) showed the woutersi-complex sensu Hołyńska (2000) para- or polyphyletic rather than monophyletic, while M. microlasius, M. geminus and M. ogunnus were united with some members of the woutersi-complex in a clade. Our present reconstructions include all the taxa mentioned above, plus some represen- tatives of three other, relatively closely related groups [Afro-Asian dussarti-clade: M. thermocyclopoides (SE/E Asia); Afro-Asian aequatorialis-affinis clade: M. affinis (New Guinea-SE Asia); Australian-South Pacific clade: M. roberti (Fiji/Wallis)] as outgroups.

The unordered and scaled reconstructions and six of the seven shortest trees of the unscaled reconstruction show the woutersi-complex paraphyletic, yet support monophyly of a predominantly Oriental group (Fig. 11, clade E) comprising: $M$. friendorum (Sulawesi), M. geminus (Borneo), M. microlasius (Luzon, Mindanao), $M$. francisci (Sumatra, Malaysia Cambodia), M. parentium (India, Sri Lanka, Cambodia), M. woutersi (Australia, New Guinea, Vanuatu, Laos, Vietnam, Taiwan, South China, Japan, South Korea), M. dissimilis [China, Japan, South Korea, Russian Far East (Primorskiy)], and M. augusti n. sp. (Mindanao, Vietnam) [occurrence data on Cambodia from Chaicharoen (2011)]. Clade E is supported by at least one apomorhy (Tab. 5) (char 10:0, joint canal present). Another derived feature, spinules of unequal size near the proximal margin of P4 coxopodite (char 8:2), also defines this clade in some trees of the $u n$ scaled run and in most of the unordered and scaled trees. The character of small spinules in anterior part of proctodeum (char 13:1) as third apomorphy of clade E only shows up in the unordered reconstruction. In these reconstructions the unique apomorphy of clade $\mathrm{E}$ is the joint

Tab. 5. Apomorphies of the clades revealed in phylogenetic reconstructions obtained by applying different coding of the polymorphic characters.

\begin{tabular}{lccc}
\hline Clades & Unordered [15] & Unscaled [7] & Scaled [3] \\
\hline A & $9(1>0)$ & $9(1>0)$ & $9(1>0)$ \\
& $12(0>1)^{*}$ & $12(0>1)^{*}$ & $12(0>1)^{*}$ \\
& & $16(2>0)$ & $16(2>0)$ \\
\hline B & $1(0>1)^{*}$ & $1(0>1)^{*}$ & $1(0>1)^{*}$ \\
& & $11(1>0)$ & $11(1>0)$ \\
\hline $\mathrm{C}$ & - & $4(0>1)$ & $4(0>1)$ \\
\hline $\mathrm{D}$ & - & $6(0>1)$ & $6(0>1)$ \\
& & $16(1>2)$ & $16(1>2)$ \\
\hline $\mathrm{E}$ & $10(2>0)^{*}$ & $10(2>0)^{*}, \circ$ & $10(2>0)^{*}$ \\
& $13(0>1)$ & & \\
\hline F & $15(0>1)^{*}$ & - & $11(1>0)$ \\
& & & $15(0>1)^{*}$ \\
\hline
\end{tabular}

-, node was present in some trees, but collapsed in the strict consensus tree. ${ }^{*}$ Unique apomorphies in the group analysed; ${ }^{\circ}$ clade E was present in six of the seven shortest trees of the unscaled recontruction. Letters denoting clades refer to the groups indicated in Fig. 11. Only those apomorphic transformations that occur in all shortest trees of a particular reconstruction are listed here. Number of all shortest trees is given in brackets after the name of the reconstructon. For number codes of the characters and character states see Supplementary Material B. Numbers in parentheses show character state transformations. 
canal, which is formed by the fusion of the transverse duct-like structures, anteriorly to the copulatory pore. This character state, however, appears in most New World species and also present in several Old World taxa (including the more basal species, e.g. M. cuttacuttae Dumont et Maas, 1985, M. rarus Kiefer, 1981, M. annae Kiefer, 1930, M. splendidus Lindberg, 1943, M. salinus Onabaniro, 1957, and M. brevisetosus Dussart et Fernando, 1985), which implies that joint canal is either a plesiomorphy or a character reversal (apomorphy) in group E. As the outgroups determine the character polarity and also influnce the tree topology, we may need an analysis with larger taxon sampling to verify the diagnostic value of joint canal and test the monophyly of group $\mathrm{E}$ (this was beyond the goals of this work).

None of the reconstructions supports sister relationships of the two Philippine taxa. Instead, in all analyses the closest relative of M. augusti (Mindanao, North Vietnam) is M. dissimilis (East Asia), while in all shortest trees of the unordered and scaled reconstructions and some trees ( 3 of 7) of the unscaled run the sister of M. microlasius (Luzon, Mindanao) is M. geminus (East Borneo). At

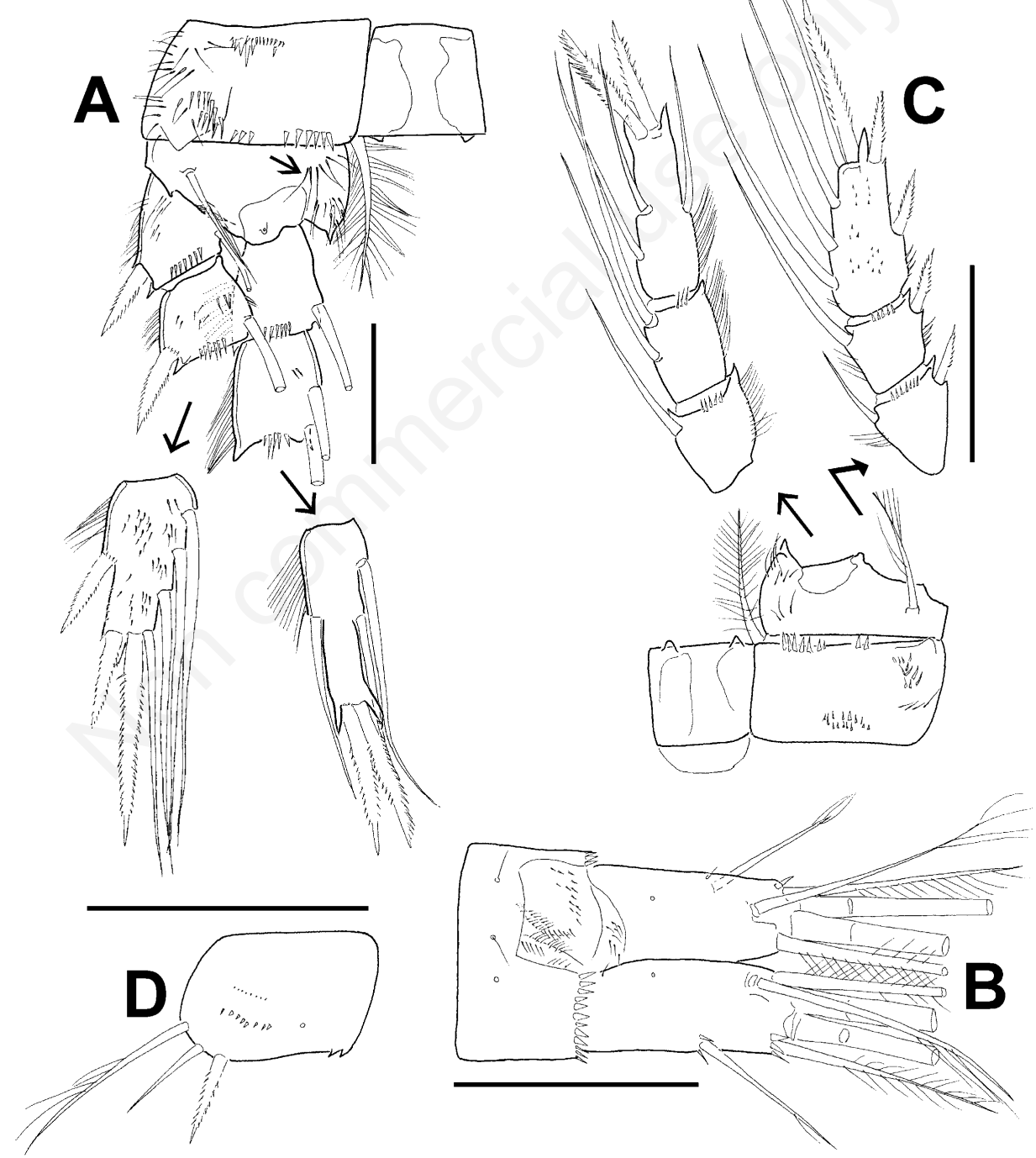

Fig. 8. A) Mesocyclops microlasius Kiefer, 1981 (L. Paoay, Luzon): female; Mesocyclops microlasius Kiefer, 1981 (L. Paoay, Luzon): male. A) shows MIZ:5/2013/17, B and C) show MIZ:5/2013/19, and D) shows MIZ:5/2013/21. A) leg 4, caudal (short arrow points to row of long medial hair on basipodite, long arrows point to terminal segments of exo- and endopodite); B) anal somite and caudal rami, laterocaudal; C) leg 4, caudal (long arrows indicate exo- and endopodite); D) leg 6. Scale bars: $50 \mu \mathrm{m}$. 
least two apomorphies support the dissimilis-augustus group (clade A in Fig. 11 and in Tab. 5) (char 9:0, many spinules on lateral margin of medial apical spine of P4 enp3; and char 12:1, eight pores sometimes present posteriorly to P6), while a third apomorphy [char 16:0, spinules present at insertion of lateral (II) caudal setae] also appears in all shortest trees of the unscaled and scaled reconstructions and in some trees of the unordered run. Eight pores posteriorly to $\mathrm{P} 6$ is an unique feature of clade A. There are relatively few taxa where this character have been verified, but at least in one species that was not in- cluded in our analysis, M. aequatorialis Kiefer, 1929 (the presumed sister of $M$. affinis), the eight-pore state sometimes occurs. Mesocyclops augusti n. sp. differs from $M$. dissimilis in the surface ornamentation of the hindgut in female (long spinules posteriorly present in M. augusti yet absent in $M$. dissimilis) (Fig. 2E and 2F vs 2G). There are also four male features that help to distinguish these species: i) the surface ornamentation of the antennulary segments (in $M$. augusti spinules present on segment 1 only, while in $M$. dissimilis spinules present on segments 1, and 12-13); ii) length proportions of P6 setae (median

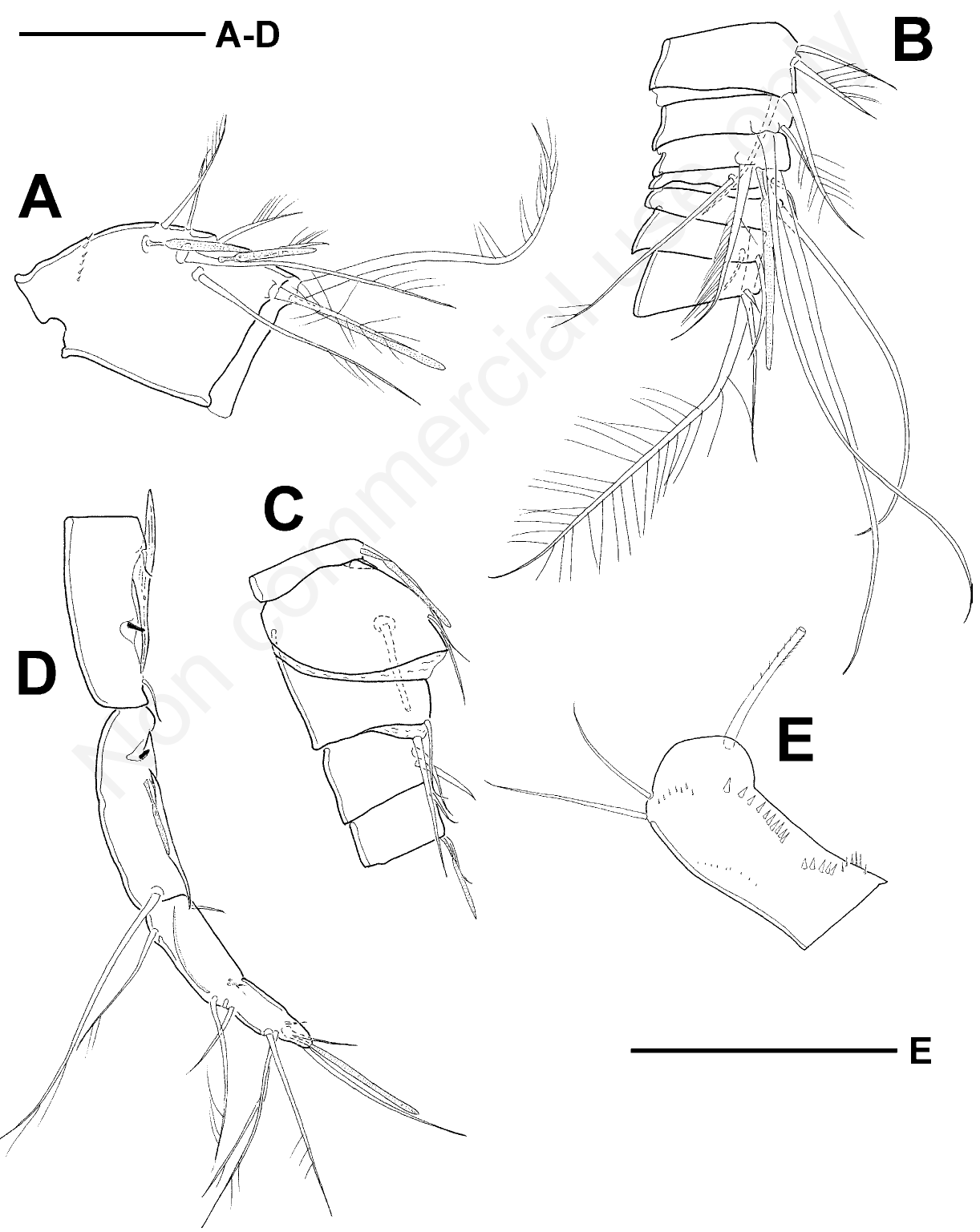

Fig. 9. Mesocyclops microlasius Kiefer, 1981, male (L. Paoay, Luzon): antennule, anterior. A-D) show MIZ:5/2013/20, and E) shows MIZ:5/2013/19. A) segment 1; B) segments 2-8; C) segments 9-13; D) segments 14-16; E) antennal coxobasis. Scale bars: $50 \mu \mathrm{m}$. 
seta subequal or shorter than medial spine in M. augusti, yet min. 1.3 times as long in M. dissimilis) (Fig. 6D vs 6B); iii) surface ornamentation of P6 flap (many transverse rows of spinules in $M$. augusti, yet no ornamentation in M. dissimilis) (Fig. 6A vs 6B); iv) and lateral pilosity of pediger 5 (short lateral hair in M. augusti, no hair in $M$. dissimilis) (Fig. 6A vs 6B).

Clade B (Fig. 11), comprising M. augusti, M. dissimilis and $M$. woutersi also appears in all the reconstructions. Two apomorphies define this clade in all shortest trees of the scaled and unscaled run, and in majority ( 9 of 15) of the trees in the unordered run (Tab. 5): spinules can be present on $14^{\text {th }}$ antennulary segment (char 1:1), and the pilosity of pediger 5 is reduced to the lateral surface (char 11:0). The presence of spinules on the $14^{\text {th }}$ antennulary segment is an unique feature of clade $\mathrm{B}$, and it is a rare character state in the whole genus also. Spinules sometimes present on the $14^{\text {th }}$ antennulary segment in $M$. aequatorialis, and always present in the species of the Afro-Asian dussarti-clade (but not in M. thermocyclopoides included here).

The microlasius-geminus group (clade F in Fig. 11 and Tab. 5) is defined by at least one apomorphy (char 15:1, hair or long spinules present on anterior half of caudal rami). A second (but not unique) apomorphy (char 11:0, pilosity of pediger 5 is restricted to the lateral surface) appears in all trees of the scaled run, in majority ( 9 of 15) of the unordered trees, and in three trees of the unscaled run where this node shows up. Hair/spinules restricted to anterior half of the caudal rami (unique apomorphy here) only appear in few Old World taxa, M. pilosus Kiefer, 1930, M. insulensis Dussart, 1982, M. mariae Guo, 2000, M. spinosus Van de Velde, 1984, M. shenzhenensis Guo 2000 and M. pseudopinosus Dussart et Fernando 1988. Mesocyclops microlasius differs from M. geminus in: caudal surface ornamentation of the antennal coxobasis (spinules in group f small in M. microlasius, yet large in $M$. geminus); caudal surface ornamentation of $\mathrm{P} 4$ coxopodite (spinules of unequal size near proximal margin in $M . m i-$ crolasius, yet equal size in M. geminus); laterofrontal ornamentation of $\mathrm{P} 4$ basipodite (long spinules absent in $M$. microlasius, yet present in M. geminus).

The unscaled and scaled trees and majority ( 8 of 15) of the trees in the unordered run support a mainland clade (Fig. 11, clade D), members of which, albeit can also show up in islands that have never been connected to the SE Asian shelf, occur in continental Asia. In most trees with the mainland clade (except for one tree in the unscaled reconstruction, where $M$. geminus groups with $M$. ogunnus and $M$. thermocyclopoides) the insular taxa (M. microlasius, $M$. geminus, $M$. friendorum) either form a paraphyletic group (basal to mainland clade), or constitute a monophyletic group, the sister of the mainland clade. Two apomorphies [char 6:1, row of spinules between dis- tal hair of labrum and epistoma; and char 16:2, spinules absent at implantation of lateral (II) caudal seta] diagnose the mainland clade in all trees of the unscaled and scaled run. From among the eight trees of the unordered run where the mainland clade appears, in five trees two apomorphies (char 6:1; char 16:2) and in three trees only one apomorphy (char 6:1) supports monophyly of clade D. Nonetheless, to propose a robust hypothesis of the relationship of the mainland clade to the insular species, or to answer the question whether the insular group would be more basal to the mainland group, we need a wider context, i.e. an analysis with larger taxon sampling.

\section{Geographic distribution patterns of the limnetic Cyclopidae in the Philippines}

Our samplings emphasised the limnetic fauna and our results suggest that interesting taxa may still be found even in this usually less diverse habitat. This is shown with the discovery of two new records including one new species. It also shows how scarce information is on copepods in most Philippine lakes, in spite of their utilisation for local fisheries and aquaculture. Many other lakes and islands have yet to be sampled, which, in time, may yield equally interesting species, and give a more complete picture of the zooplankton fauna of the Philippines.

The endemic Mesocyclops microlasius seems to have a wider distribution than previously thought. Our collections reveal that beyond the Manila region (type locality) the species is also present in northern Luzon. The farthest record comes from lake Sebu in Mindanao island (Tuyor and Baay, 2001), yet we could not find the species in our sample (Tab. 4, lake 21). We think that Mindanao occurrence might need further confirmation. Sister relationship of Mesocycyclops microlasius (Luzon, Mindanao) and $M$. geminus (East Borneo) are in line with the observation made in several primary freshwater fishes, molluscs and crabs in which the Philippine forms (mainly those from the southwestern and southern islands) have their closest relatives in Borneo (Bănărescu, 1992). It is premature to make inferences about the geographic distribution of $M$. augusti sp. $\mathrm{n}$. in the Philippines, yet absence of the species in all the 15 lakes that we sampled in Luzon might indicate that species does not occur in northern Philippines. On the other hand, $M$. augusti sp. n. has been identified from North Vietnam, and its closest relative, M. dissimilis, is distributed in East Asia (but not found in Taiwan). Our guess is that $M$. august $i \mathrm{sp} \mathrm{n}$. might use a southern colonisation route via Borneo between Vietnam and Mindanao.

In contrast, two other cyclopids, M. thermocyclopoides (Luzon and Mindoro) and T. taihokuensis (Luzon), have been encountered in the northern islands only, yet scarce sampling in the southern part leave some doubts about the restricted northern distributions of these taxa. At least the study by Tuyor and Baay (2001) reported 
M. thermocyclopoides in Calamba river (Luzon) and lake Mainit (Mindanao). It is possible that some of the previous records of Mesocyclops leuckarti (a Palearctic species) in the Philippines (Woltereck et al., 1941; Mamaril Sr. and Fernando, 1978; Mamaril Sr., 1986, 2001) (Tab. 1) may actually refer to $M$. thermocyclopoides, given the wide distribution of the latter species in Northern Philippines. Also, most localities and lakes where we found $M$. thermocyclopoides were sites where $M$. leuckarti has been previously recorded from, such as Laguna de Bay and lake Naujan. Based on the widespread occurrence of $M$. thermocyclopoides among the neigh- bouring countries such as Indonesia (Flores, Java and Sumatra), Malaysia, Thailand, Cambodia, Vietnam, China and Taiwan (Hołyńska et al., 2003; Alekseev and Sanoamuang, 2006; Hołyńska and Stoch, 2011; Chaicharoen, 2011), and widespread distribution of the species in Luzon, we think that $M$. thermocyclopoides is a native species rather than introduced by humans in the Philippines. The distribution of the newly recorded $T$. taihokuensis in the Philippines (Luzon), meanwhile, seems to be restricted to clusters of lakes near one another, as lakes Pandin, Bunot, Mohicap and Palakpakin all located in one town (San Pablo, total area: $214 \mathrm{~km}^{2}$ ), while lakes

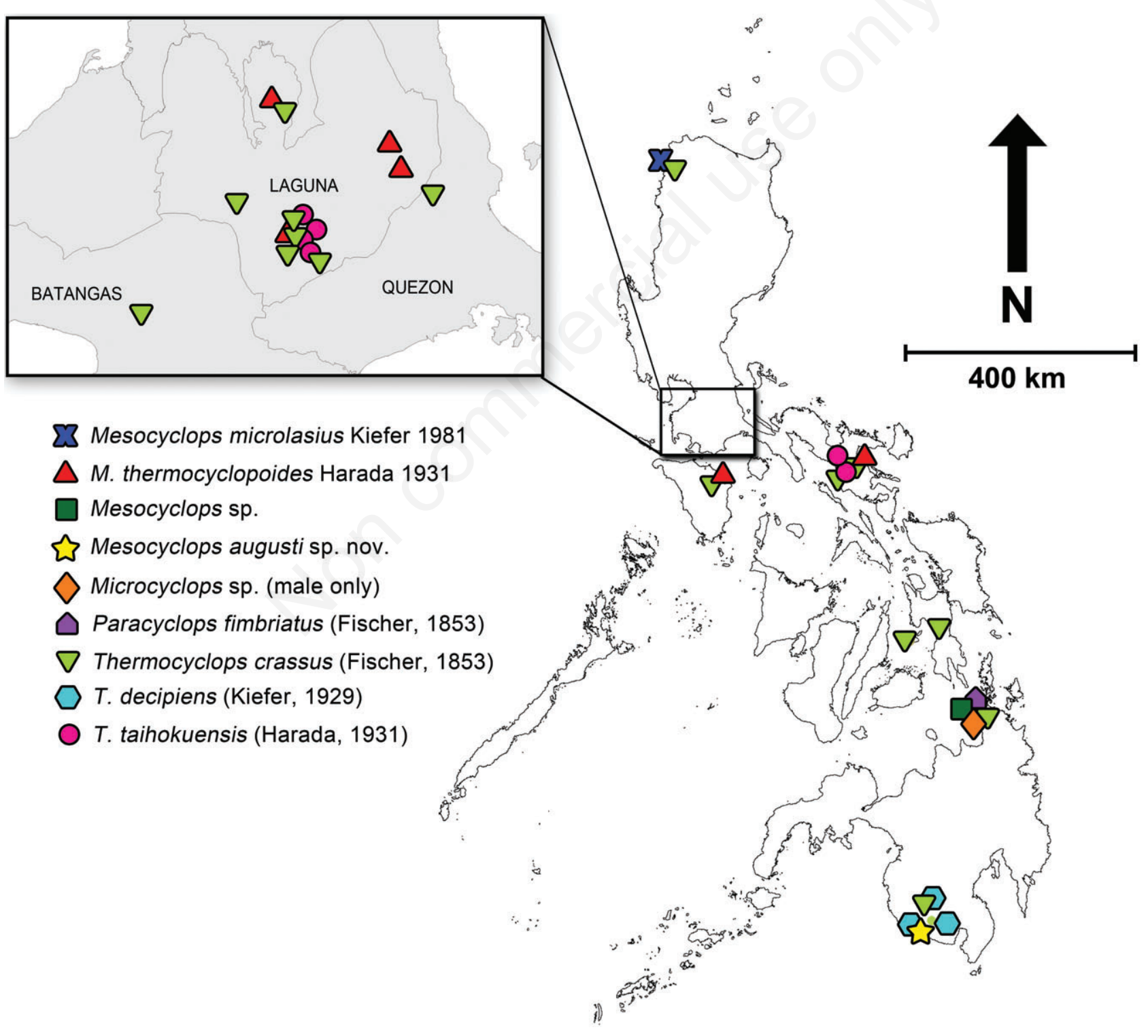

Fig. 10. Distribution map of the nine cyclopid taxa encountered in the 22 lakes sampled throughout the Philippine archipelago. 
Buhi and Baao are approximately $15 \mathrm{~km}$ from each other in the province of Camarines Sur. The closest records of East/Central Asian T. taihokuensis are those from Vietnam and Taiwan (Mirabdullayev et al., 2003), and we speculate that $T$. taihokuensis reached Luzon from Taiwan.
Colonisation of the northern Philippine Batanes islands from Taiwan has been evidenced in small mammals (shrews) (Esselstyn and Oliveros, 2010).

The ubiquitous nature of $T$. crassus (Old World) in the Philippines is consistent with the results of other studies on
A<smiles>[CH2+]CC1CC1</smiles>
ROBE<smiles>CC(C)C</smiles>
THER
OGUN
FRIE
FRAN
PARE MEMI
MICR WOUT
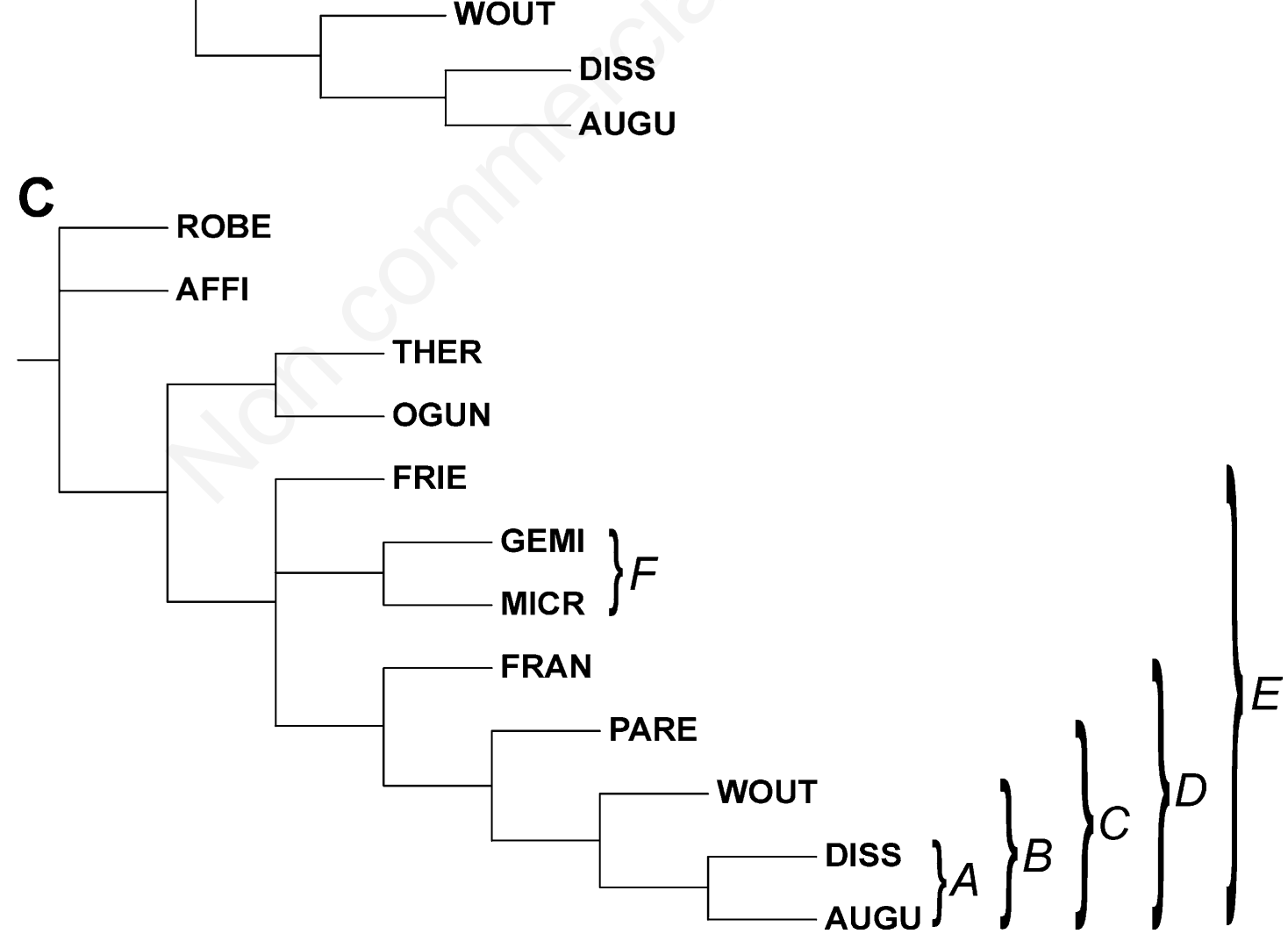

Fig. 11. Strict consensus trees of the parsimony analyses obtained by applying different coding of the polymorphic characters. A) unordered coding [15 shortest trees; length 44; ci: 61; ri: 58]; B) unscaled coding [7 shortest trees, length: 53; ci: 52; ri: 55]; C) scaled coding [3 shortest trees; length 71; ci: 54; ri: 56]. Codes of the taxa are listed under Comparative material section in the description of Mesocyclops augusti n. sp. (beginning of Results section). 
its distribution (Hołyńska, 2006a; Chaicharoen et al., 2011). Furthermore, studies in lake Taal have shown how T. crassus is the most abundant copepod in the lake compared to calanoids and how this was related to the increased trophic status of the lake from the excessive nutrient inputs in aquaculture areas (Papa and Zafaralla, 2011; Papa et al., 2011).

This is also the second record of T. decipiens in Mindanao island, where it has been observed in three lakes within the same locality (South Cotabato). Tuyor and Baay (2001) found T. decipiens in lake Mainit, Mindanao, while Hołyńska (2006a) reported it from ponds in the town of Dasmariñas (Cavite province, Luzon island). It is not surprising to find more localities with $T$. decipiens in the Philippines (Tab. 1) as it is a widely distributed Pantropical species (Chaicharoen et al., 2011).

We failed to find two species that were also known from limnetic waters in the Philippines. Thermocyclops wolterecki Kiefer, 1938 has originally been described from the plankton of lake Lanao (Mindanao), and later reported from lake Pogera in Papua New Guinea (Defaye et al., 1987) and lake La Han in Northeast Thailand (Alekseev and Sanoamuang, 2006). Interestingly, Chaicharoen et al. (2011) found the species in small water bodies (canal, stream and temporary pond) in Cambodia. In comparison with the Lanao specimens, the Cambodian females had larger body, shorter caudal setae (V and VII) and slightly different surface ornamentation on the P4 coupler, but the morphology otherwise fit that in the type locality. We suppose that $T$. wolterecki occurs in small waterbodies in the Philippines too, and the small and slender form in lake Lanao is a pelagic ecotype of the species. Tropocyclops prasinus (Fischer, 1860) was reported from Luzon, Cebu and Mindanao islands (Tab. 1). The species is recorded from almost every continent, yet recent morphological studies (Lee and Chang, 2007) on the East Asian T. prasinus-like forms showed that a few good species with more restricted distribution could be hidden under this name. Tropocyclops of the Philippines also needs revision.

In the Philippines, the threat of non-indigenous species taking over native zooplankton fauna has already been observed among calanoid copepods. A Neotropical species, Arctodiaptomus dorsalis (Marsh, 1932) was found in most of the lakes sampled in this study. Previously recorded native calanoid copepods have already been displaced by $A$. dorsalis (Papa et al., 2012). Importantly enough, there has been no similar occurrence in the cyclopid fauna; however, with the presence of aquaculture and its role in the dispersal of non-indigenous zooplankton species (Reid, 2007), in most Philippine lakes the threat still remains.

\section{CONCLUSIONS}

Two genera, Mesocyclops (4 species) and Thermocyclops (4 species), dominate the relatively poor open-water fauna of the lakes in the Philippines (11 species), among which only one species (M. microlasius) seems to be endemic to the archipelago. Our paper currently brings the total number of cyclopid copepods (including both limnetic and littoral/benthic taxa) known from the Philippines to 18 , but more importantly, it highlights the need for more intensive investigations in the small water bodies, paludal and subterranean habitats, which may be home to a significantly richer fauna with higher rate of endemism.

Former phylogenetic analyses that included all species of the genus Mesocyclops, and a present reconstruction that was restricted to the Oriental representatives of the genus revealed that: i) all Mesocyclops species so far recorded from the Philippines are nested in clades occurring predominantly in the tropical Asian mainland and/or the Greater Sunda islands; ii) the closest relative of M. augusti n. sp. (Mindanao, North Vietnam) is M. dissimilis (East Asia); and iii) the closest relative of M. microlasius (Luzon, Mindanao) is M. geminus (East Borneo).

Exploring the species diversity and geographic distribution of Cyclopidae in the Philippines may have implications for human epidemiology as well. The potential use of cyclopid copepods (e.g. Mesocyclops), as biological control agents of Dengue-carrying Aedes mosquitoes should be considered, as Dengue continues to be one of the leading causes of mortality among Filipinos.

\section{ACKNOWLEDGMENTS}

The first author would like to thank D. Tordesillas, H. $\mathrm{Li}, \mathrm{H}$. Dumont, J. Briones and B. Han for help in collecting samples from May to November 2011 and University of Santo Tomas undergraduate biology students for sample collection in lakes Paoay and Laguna de Bay in 2006. G. Adorable helped with the sample processing and V. Garcia helped to create the maps. Funds for sample collection were obtained from the Research Center for the Natural and Applied Sciences, University of Santo Tomas, and the Philippine Council for Aquatic and Marine Research and Development. Support from the World Association of Copepodologists to the first author is greatly appreciated for participation in the DEST - Expert-in-Training Program at the Museum and Institute of Zoology, Warsaw, Poland. The programme Southeast Asian - European Year of Science and Technology 2012 European Commission's Seventh Framework Programme for Research and Technological Development (FP7) sponsored the participation of the second author in the FISA workshop.

\section{REFERENCES}

Alekseev V, Sanoamuang L, 2006. Biodiversity of cyclopoid copepods in Thailand - with a description of Afrocyclops henrii sp. n. Arthropoda Sel. 15:277-290.

Anneville O, Molinero JC, Souissi S, Balvay G, Gerdeaux D, 2007. Long-term changes in the copepod community of lake Geneva. J. Plankton Res. 29:49-59. 
Aquino R, Cho C, Cruz MA, Saguiguit A, Papa RDS, 2008. Zooplankton composition and diversity in Paoay lake, Luzon is., Philippines. Philipp. J. Sci. 137:169-177.

Balian EV, Lévèque C, Segers H, Martens K, 2008. Freshwater animal biodiversity assessment. Springer, Dordrecht: 640 pp.

Bănărescu P, 1992. Zoogeography of fresh waters. Distribution and dispersal of freshwater animals in North America and Eurasia. AULA-Verlag, Wiesbaden: 580 pp.

Bănărescu P, 1995. Zoogeography of fresh waters. Distribution and dispersal of freshwater animals in Africa, Pacific areas and South America. AULA-Verlag, Wiesbaden.

Boxshall GA, Defaye D, 2008. Global diversity of copepods (Crustacea: Copepoda) in freshwater. Hydrobiologia 595:195-207.

Brancelj A, Boonyanusith C, Watiroyram S, Sanoamuang L, 2013. The groundwater-dwelling fauna in South East Asia. J. Limnol. 72(Suppl.2):e16.

Brehm V, 1938. [Die Cladoceren der Wallacea-Expedition]. [Article in German]. Int. Rev. Ges. Hydrobio. 38:99-124.

Brehm V, 1942. [Über die Diaptomiden und Pseudodiaptomiden der Zwischenregion Wallacea]. [Article in German]. Int. Rev. Ges. Hydrobio. 41:269-287.

Chaicharoen R, 2011. Diversity and distribution of freshwater calanoid and cyclopoid copepods in seven provinces of Cambodia. PhD thesis. Khon Kaen University ed., Khon Kaen, Thailand.

Chaicharoen R, Sanoamuang L-o, Hołyńska M, 2011. A review of the genus Thermocyclops (Crustacea: Copepoda: Cyclopoida) in Cambodia. Zool. Stud. 50:780-803.

Chih-hao H, Sakai Y, Ban S, Ishikawa K, Ishikawa T, Ichise S, Yamamura N, Kumagai M, 2011. Eutrophication and warming effects on long-term variation of zooplankton in lake Biwa. Biogeosciences 8:593-629.

de Elera C, 1895. [Catalogo sistematico de toda la fauna de Filipinas, II: articulados]. [Book in Spanish]. Colegio-Universidad de Santo Tomas ed., Manila: 942 pp.

Defaye D, Dussart BH, Fernando CH, Sarnita AS, 1987. On some species of the genus Thermocyclops (Crustacea, Copepoda) from the Oriental Region. Can. J. Zool. 65:3144-3153.

Dussart BH, Defaye D, 2001. Introduction to the Copepoda. Backhuys Publ., Leiden: 344 pp.

Esselstyn JA, Oliveros CH, 2010. Colonization of the Philippines from Taiwan: a multi-locus test of the biogeographic and phylogenetic relationships of isolated populations of shrews. J. Biogeogr. 37:1504-1514.

Hauer J, 1941. [Rotatorien aus dem Zwischengebiet Wallacea]. [Article in German]. Int. Rev. Ges. Hydrobio. 41:177-203.

Hołyńska M, 1997. Tracing the routes of speciation in Mesocyclops woutersi-superspecies (Copepoda: Cyclopoida). Ann. Zool. 47:321-336.

Hołyńska M, 2000. Revision of the Australasian species of the genus Mesocyclops Sars, 1914 (Copepoda: Cyclopidae). Ann. Zool. 50:363-447.

Hołyńska M, 2006a. On species of the genus Thermocyclops (Copepoda: Cyclopidae) occurring in Northern Queensland, Australia. Ann. Zool. 56:335-367.

Hołyńska M, 2006b. Phylogeny of Mesocyclops (Copepoda: Cyclopidae) inferred from morphological characters. Zool. J. Linn. Soc.-Lond. 147:1-70.

Hołyńska M, Reid JW, Ueda H, 2003. Genus Mesocyclops Sars,
1914. p. 12-213. In: H. Ueda and J.W. Reid (eds.), Copepoda: Cyclopoida. Genera Mesocyclops and Thermocyclops.. Backhuys Publ.

Hołyńska M, Stoch F, 2011. Mesocyclops (Crustacea, Copepoda, Cyclopidae) in the South Pacific Islands. Zool. Anz. 251:237-252.

Huys R, Boxshall GA, 1991. Copepod evolution. The Ray Society ed., London: 468 pp.

Jones AW, Kennedy RS, 2008. Evolution in a tropical archipelago: comparative phylogeography of Philippine fauna and flora reveals complex patterns of colonization and diversification. Biol. J. Linn. Soc. 95:620-639.

Karaytug S, 1999. Copepoda: Cyclopoida Genera Paracyclops, Ochridacyclops and key to the Eucyclopinae. Backhuys Publ., Leiden: 217 pp.

Kiefer F, 1938a. [Bemerkungen zur Pseudodiaptomiden aus beute der Wallacea-Expedition]. [Article in German]. Int. Rev. Ges. Hydrobio. 38:75-98.

Kiefer F, 1938b. [Die von der Wallacea-Expedition gesammelten Arten der Gattung Thermocyclops Kiefer]. [Article in German]. Int. Rev. Ges. Hydrobio. 38:54-74.

Kiefer F, 1981. [Beitrag zur Kenntnis von Morphologie, Taxonomie und geographischer Verbreitung von Mesocyclops leuckarti auctorum]. [Article in German]. Arch. Hydrobiol. Suppl. 62:148-190.

Lee JM, Chang CY, 2007. Two new species of Tropocyclops prasinus groups (Copepoda: Cyclopidae) from South Korea. Integr. Biosci. 11:255-263.

Mamaril Sr. AC, 1986. Zooplankton guide to Philippine flora and fauna. NRMC and UP Diliman Publ., Quezon City: 268 pp.

Mamaril Sr. AC, 2001. Zooplankton diversity in Philippine lakes, p. 81-93. In: C.B. Santiago, Ma.L. Cuvin-Aralar, Z.U. Basiao (eds.), Conservation and ecological management of Philippine lakes in relation to fisheries and aquaculture. Southeast Asian Fisheries Development Center, Aquaculture Department ed.

Mamaril Sr. AC, Fernando CH, 1978. Freshwater zooplankton of the Philippines: Rotifera, Cladocera and Copepoda. Nat. App. Sci. Bull. 30:109-221.

Mirabdullayev IM, Reid JV, Ueda H, 2003. Genus Thermocyclops Kiefer, 1927, p. 214-302. In: H. Ueda and J.W. Reid (eds.), Copepoda: Cyclopoida. Genera Mesocyclops and Thermocyclops. Backhuys Publ.

Marsh CD, 1932. A new species of Cyclops from the Philippine islands. J. Wash. Acad. Sci. 22:182-184.

Nam VS, Tien TV, Huan TQ, Yen NT, Kay B, Marchand R, Marten G, Holynska M, Reid J, 1999. Mesocyclops of Vietnam. Laboratory evaluation as biological agent for control of Aedes aegypti. Dengue Bull. 23:89-93.

Nixon KC, 1999-2002. WinClada ver. 1.0000. Nixon ed., Ithaca, NY.

Ong PS, Afuang LE, Rosell-Ambal RG, 2002. Philippine biodiversity conservation priorities: a second iteration of the national biodiversity strategy and action plan. Department of Environment and Natural Resources-Protected Areas and Wildlife Bureau, Conservation International-Philippines, Biodiversity Conservation Program-University of the Philippines Center for Integrative and Development Studies, and Foundation for Philippine Environment ed., Quezon City, Philippines: 113 pp. 
Palerud R, Christensen G, Legovic T, White P, Regpala R, 2008. Environmental and production survey methodology to estimate severity and extent of aquaculture impact in three areas of the Philippines. Sci. Diliman 20:23-29.

Panogadia-Reyes CM, Cruz EI, Bautista SL, 2004. Philippine species of Mesocyclops (Crustacea: Copepoda) as a biological control agent of Aedes aegypti (Linnaeus). Dengue Bull. 28:174-178.

Papa RDS, Li H, Tordesillas DT, Han B-P, Dumont H, 2012. Massive invasion of Arctodiaptomus dorsalis (Copepoda, Calanoida, Diaptomidae) in Philippine lakes: a threat to Asian zooplankton biodiversity? Biol. Invasions 14:24712478

Papa RDS, Mamaril Sr. AC, 2011. History of the biodiversity and limno-ecological studies in lake Taal with notes on the current status of Philippine limnology. Philipp. Sci. Lett. 4:1-10.

Papa RDS, Pagulayan RC, Pagulayan AEJ, 2008. Zooplanktivory in the endemic freshwater sardine, Sardinella tawilis (Herre 1927) of Taal lake, the Philippines. Zool. Stud. 47:535-543.

Papa RDS, Zafaralla MT, 2011. The composition, diversity and community dynamics of limnetic zooplankton in a tropical caldera lake (lake Taal, Philippines). Raffles B. Zool. 59:1-7.

Papa RDS, Zafaralla MT, Eckmann R, 2011. Spatio-temporal variation of the zooplankton community in a tropical caldera lake with intensive aquaculture (lake Taal, Philippines). Hydrobiologia 664:119-133.

Petersen F, Carlos M, 1984. A review of zooplankton in Philippine lakes. Fish. Res. J. Philipp. 9:56-64.

Reid JW, 2007. Arctodiaptomus dorsalis (Marsh): a case history of copepod dispersal. Banisteria 30:3-18.

Sathiamurthy E, Voris HK, 2006. Maps of Holocene sea level transgression and submerged lakes on the Sunda Shelf. The Natural History Journal of Chulalongkorn University Suppl.2:1-44. Available from: http://research.rmutp.ac.th/ paper/cu/VorisSupplement.pdf

Sinha C, Heaney LR, 2006. Philippine biodiversity: principles and practice. Haribon Foundation for the Conservation of Natural Resources ed., Quezon City: 495 pp.

Tamayo-Zafaralla M, Santos RAV, Orozco RP, Elegado GCP, 2002. The ecological status of lake Laguna de Bay, Philippines. Aquat. Ecosysyst. Health 5:127-138.

Tuyor JB, Baay MO, 2001. Contribution to the knowledge of the freshwater Copepoda of the Philippines. Asia Life Sci. 10:35-43.

Ueda H, Reid JW, 2003. Copepoda: Cyclopoida Genera Mesocyclops and Thermocyclops. Backhuys Publ., Leiden: 318 pp.

Van Damme K, Maiphae S, Sa-ardrit P, 2013. Inland swamps in South East Asia harbour hidden cladoceran diversities: species richness and the description of a new paludal Chydoridae (Crustacea: Branchiopoda: Cladocera) from Southern Thailand. J. Limnol. 72(Suppl.2):e10.

Voris HK, 2000. Maps of Pleistocene sea levels in Southeast Asia: shorelines, river systems and time durations. J. Biogeogr. 27:1153-1167.

Wiens JJ, 2000. Coding morphological variation within species and higher taxa for phylogenetic analysis, p. 115-145. In: J.J. Wiens (ed.), Phylogenetic analysis of morphological data. Smithsonian Institution Press.

Woltereck R, Tressler WS, Bunag DM, 1941. [Die Seen und Inseln der Wallacea-Zwischenregion und ihre endemische Tierwelt. Zweiter Teil: Inseln und Seen der Philippinen]. [Article in German]. Int. Rev. Ges. Hydrobio. 30:37-76. 